Trinity University

Digital Commons@ Trinity

English Faculty Research

English Department

$10-2019$

\title{
Rolle Reassembled: Booklet Production, Single- Author Anthologies, and the Making of Bodley 861
}

Andrew B. Kraebel

TrinityUniversity, akraebel@trinity.edu

Follow this and additional works at: https://digitalcommons.trinity.edu/eng_faculty

Part of the English Language and Literature Commons

\section{Repository Citation}

Kraebel, A. (2019). Rolle reassembled: Booklet production, single-author anthologies, and the making of bodley 861. Speculum, 94(4), 959-1005. doi:10.1086/705376

This Article is brought to you for free and open access by the English Department at Digital Commons @ Trinity. It has been accepted for inclusion in English Faculty Research by an authorized administrator of Digital Commons@ Trinity. For more information, please contact jcostanz@trinity.edu. 


\title{
Rolle Reassembled: Booklet Production, Single- Author Anthologies, and the Making of Bodley 861
}

\author{
By Andrew Kraebel
}

The assignment of value to manuscripts on the basis of their antiquity-that is, the notion that books written at a greater distance from the present were therefore more deserving of attention-reflects a sensibility more commonly associated with early modern collectors than with medieval scribes. Malcolm Parkes, for example, though describing many instances of archaizing hands in medieval manuscripts, tends to see these as pragmatic efforts driven by "the need to copy replacement leaves," a more practical aim than the Tudor valuing of medieval scripts, which "came to be perceived as emblematic of the past." Within this framework, though generally accurate, it is hard to account for the scribe who wrote Oxford, Bodleian Library, MS Bodley 861, one of the largest single-volume anthologies of the Latin writings of Richard Rolle, the Hermit of Hampole (d. 1349). ${ }^{2}$ In a marginal note on fol. 10r, this scribe first adds a gloss on a portion of Ps. 21.29 that had not appeared in his initial exemplar of the commentary known as Rolle's Latin Psalter, and then, rather than simply marking it for insertion, he registers concerns arising from the relative dating of his sources:

I have silently expanded abbreviations and standardized capitalization and punctuation for all quotations from manuscripts, though retaining the manuscripts' orthography; emendations are supplied in square brackets. For reading and offering comments on earlier drafts, and for answering specific questions, I am very grateful to Ralph Hanna, Barbara Shailor, Richard Sharpe, Daniel Wakelin, Margaret Connolly, Erik Kwakkel, Michael Van Dussen, Sonja Drimmer, Aaron Pratt, Barbara Newman, and Alastair Minnis. Feedback from the readers for Speculum greatly improved the essay's scope and argument, and valuable information about Hereford O.VIII.1 was graciously provided by Rosemary Firman. The diagrams in Figs. 1 and 2 were prepared by Vanessa Jaber, then an undergraduate at Trinity University. Permission to reproduce the other images was generously granted by the Bodleian Libraries, the University of Oxford, and by the Dean and Chapter of Hereford Cathedral and the Hereford Mappa Mundi Trust.

${ }^{1}$ M. B. Parkes, "Archaizing Hands in English Manuscripts," in Books and Collectors, 1200-1700: Essays Presented to Andrew Watson, ed. James P. Carley and Colin G. C. Tite (London, 1997), 101 and 123. To be sure, Parkes also identifies potential aesthetic motivations on the part of medieval scribes, noting that "another reason for imitating earlier handwriting was to produce a more legible text and a more elegant page" (103, emphasis added). See, more generally, Jennifer Summit, Memory's Library: Medieval Books in Early Modern England (Chicago, 2008), esp. 101-21.

${ }^{2}$ For descriptions, see Hope Emily Allen, Writings Ascribed to Richard Rolle, Hermit of Hampole, and Materials for His Biography (New York, 1926), 22-34; Ralph Hanna, Editing Medieval Texts: An Introduction (Liverpool, 2015), 141-48. Briefly, the volume consists of 168 paper folios measuring $290 \mathrm{~mm} \times 210 \mathrm{~mm}$, and (with the exception of some titles and material added on fols. $128 \mathrm{v}-132 \mathrm{r}$, discussed below) all its contents are written in a single Anglicana hand with secretary $a$. For reproductions of the hand, see the figures below, as well as Andrew G. Watson, Catalogue of Dated and Datable Manuscripts, c. 435-1600, in Oxford Libraries, vol. 2, The Plates (Oxford, 1984), plate 265; S. Harrison Thompson, Latin Bookhands of the Later Middle Ages, 1100-1500 (Cambridge, UK, 1969), plate 104. Subsequent references to Bodleian manuscripts use the abbreviation "BodL."

Speculum 94/4 (October 2019). Copyright 2019 by the Medieval Academy of America. doi: 10.1086/705376, 0038-7134/2019/9404-0001\$10.00. 
"Quoniam Domini est regnum, et ipse suis regnum celorum dabit morte et cruce adqu[i]situm per manifestacionem—quod ideo dico, quia omnia in [In]carnacione [? facta] erant secundum quod homo-et ipse dominabitur gencium, non tantum Iudeorum. Et non tantum pauperes sed et manducauerunt," et cetera. Non inueni istum versum in glosa Ricardi nec in borientalibus apud Hampul nec in cometatu de Richemund nec in australibus in aliquo antiquo libro sed in vno nouo scripto.

["For the kingdom is the Lord's [Ps. 21.29], and at his manifestation [in glory] he will give to his own [people] the kingdom of heaven, acquired by his Cross and death-I say this, because all things in the Incarnation were [? done] according to his humanityand he will rule over the Gentiles, not only the Jews. And not only the poor but also [the rich] have eaten [21.30]," etc. I did not find this verse in Richard's gloss—neither in the north at Hampole nor in the county of Richmond, nor in the south-in any old book but in one newly written.]

Before finding it in a "newly written" book, the scribe apparently looked for this material in several "old" copies of the Latin Psalter beyond his exemplar, though it is unclear whether his opinion on the dating of these volumes was based on script, evidence of use, or perhaps information supplied by their owners. ${ }^{3}$ In addition to potentially indicating his doubts about newer books, this note reveals that the scribe's search led him to travel throughout Yorkshire, from at least Hampole to Richmondshire; and, as we will see, other annotations indicate that his work spanned three years, from 1409 to 1411 . This scribe devoted himself to seeking out and sifting through Rolle's textual remains, the writings of "the most prominent English spiritual figure of the later Middle Ages," and his book affords rare insight into the relationship between scribal practices and more abstract understandings of authorship and the circulation of texts. ${ }^{4}$

The Bodley scribe's work was made especially challenging by the diffuse state of Rolle's writings at the start of the fifteenth century. Noting Rolle's relative isolation and lack of institutional support, Ralph Hanna has argued that his texts first circulated as "dispersed autographs directed to specific known audiences," and he further maintains that, "assuming that the Hermit retained his own copies," these texts

\footnotetext{
${ }^{3}$ This chronology is supported by a similar marginal annotation added on fol. 11va. In the course of copying Rolle's gloss on Ps. 27.4, the scribe appears to have noticed that some of the biblical text was undiscussed, and he left space equivalent to four lines blank at the foot of the column, where he later copied the missing gloss in a distinctive ink. In the margin near this addition, he writes, "Iste est secundus versus quem non inueni in glosa Ricardi Heremite nisi in nouo libro vno" (This is the second verse that I did not find in Richard Hermit's gloss, but only in a single new book). The scribe, in other words, noted the possibility of missing material as he copied Rolle's Latin Psalter, and he subsequently searched for it in other copies.

${ }^{4}$ Ralph Hanna, "Richard Rolle's Incendium amoris: A Prospectus for a Future Editor," Iournal of Medieval Latin 26 (2016): 227-61, at 227. The major account of Rolle's life and works is Nicholas Watson, Richard Rolle and the Invention of Authority, Cambridge Studies in Medieval Literature 13 (Cambridge, UK, 1991), building on the materials assembled by Allen, Writings Ascribed. Watson's study is usefully complemented by Denis Renevey, Language, Self, and Love: Hermeneutics in the Writings of Richard Rolle and the Commentaries on the Song of Songs (Cardiff, 2011); see too Hanna, "Richard Rolle and Related Works," in A Companion to Middle English Prose, ed. A. S. G. Edwards (Cambridge, UK, 2004), 19-32; and Renevey, "Looking for a Context: Rolle, Anchoritic Culture, and the Office of the Dead," in Medieval Texts in Context, ed. Graham D. Caie and Renevey (Abingdon, UK, 2008), 192-210.
}

Speculum 94/4 (October 2019) 
"remained capable of possible further differently personalized re-promulgations, with tailoring as deemed appropriate for a new recipient." ${ }_{5}^{5}$ This kind of transmission created a number of problems for the Bodley scribe and other would-be reassemblers of the Rollean corpus. First, as Hanna notes, "anyone who wanted genuine Rolle would be forced to find it among a range of book-owners, a mixed group of organisations and private individuals." "Second, while some of the Hermit's texts might have had a relatively limited circulation and could therefore prove difficult to find, others could have been sent to many recipients in a range of forms, yielding at once convenient ubiquity and potentially troublesome variation. What Hanna calls "differently personalized re-promulgations" could vary both at the level of an individual text (e.g., changes in wording or chapter divisions) and in the conjunction and arrangement of multiple texts in the volumes that Rolle "tailor[ed]" for these "new recipient[s]." Third, and arising in part from this last form of variation, is the question of how "genuine Rolle" could be distinguished from other texts that circulated with his writings-a question that becomes more vexed in light of the possibility that the Hermit adapted or simply copied works that he did not compose, but which he believed would be of interest to his readers. If, that is, Hanna is right to imagine Rolle as a scribe as well as an author, then he need not only have disseminated his own works.

Remarkably, the Bodley scribe appears to have recognized these problems, and the details of his book reveal that he had them in mind when judging different witnesses and recording this information in his emerging volume. This scribe, in other words, actively sought out multiple copies of texts and assessed their value based on his particular understanding of their author, and, at the same time, his idea of Rolle's authority seems to have developed in response to the books he found. ${ }^{8}$ Though he began by copying several of the Hermit's major works, pieces featuring the distinctive "literary persona" that Nicholas Watson has shown to be the basis of Rolle's reputation as "an authoritative 'modern master' of the spiritual life," this scribe went on to locate both variously divergent copies of these major writings and a range of shorter "derivative or conventional" pieces in which that distinctive persona is either effaced or absent. ${ }^{9}$ Such works are characteristic of what Matthew

\footnotetext{
${ }^{5}$ Ralph Hanna, “The Transmission of Richard Rolle's Latin Works,” The Library: The Transactions of the Bibliographical Society, ser. 7, 14 (2013): 313-33, at 328.

${ }^{6}$ Hanna, "Transmission," 327.

${ }^{7}$ These situations also pertain in English: Watson, Invention of Authority, 248, suggests that Warminster, Longleat House, MS 29 may be "a copy of a collection of English writings made for Margaret Kirkeby by Rolle himself, presumably when he composed and presented her with The Form of Living." Watson notes that the Longleat 29 text contains "a passage of Ego Dormio which is clearly authentic but occurs in no other manuscript, implying it is the product of an authorial revision or recopying of the work."

${ }^{8}$ In this regard, the scribe seems to have worked as something of an editor, a scholarly role more typically associated with humanist printers, e.g., Aldus Manutius or Johannes Oporinus, on whom see Carlo Dionisotti, Aldo Manuzio: Umanista e editore, Documenti sulle Arti del Libro 18 (Milan, 1995); and Leona Rostenberg, Johann Operin, Printer, Publisher, and Scholar: 1507-68 (Chicago, 1944). On humanist editors more generally, see Brian Richardson, Print Culture in Renaissance Italv: The Editor and the Vernacular Text, 1470-1600 (Cambridge, UK, 1994).

${ }^{9}$ Watson, Invention of Authority, 196 and 96.
}

Speculum 94/4 (October 2019) 
Fisher has called "scribal authorship," inasmuch as their derivativeness "opens up a space in which the pressures to delineate or to articulate the authorial do not always exclude the scribal." 10 These are the kinds of works that would typically circulate in the later Middle Ages without any authorial attribution, and indeed they may have lacked attributions in this scribe's exemplars. As someone motivated to seek out and copy as many of Rolle's writings as possible, however, this scribe did face considerable pressure "to articulate the authorial" and to determine if these derivative texts should be included in his volume of "genuine Rolle." ${ }^{11}$ Quite surprisingly, his grounds for making these judgments are largely recoverable (at least for the works he included), and, as with his treatment of differing copies of the Hermit's longer texts, they appear to have involved his careful consideration of how Rolle's potential work as a scribe could help to explain the state of the books he encountered. Certainly, in light of the various claims of late medieval book owners to possess Rolle's autographs, this interest in the Hermit as a "scribal author" is not unprecedented-but, while most owners apparently treated these books as holy remnants, the Bodley scribe regarded them as the authoritative basis on which to reassemble Rolle's corpus. ${ }^{12}$

This developing understanding of the Hermit as a writer of books (rather than texts) helps to account for the scribe's shifting approaches to the creation of his own volume, and both his changing ideas about Rolle's authority and his openness

\footnotetext{
${ }^{10}$ Matthew Fisher, Scribal Authorship and the Writing of History in Medieval England (Columbus, $\mathrm{OH}, 2012), 7$. Fisher's work extends lines of inquiry developed in the last few decades, with an interest in the particularity of manuscript copies of literary works following, especially, Bernard Cerquiglini, Éloge de la variante: Histoire critique de la philologie (Paris, 1989).

${ }^{11}$ Vincent Gillespie, "Fatherless Books: Authorship, Attribution, and Orthodoxy in Later Medieval England," in The Pseudo-Bonaventuran Lives of Christ: Exploring the Middle English Tradition, ed. Ian Johnson and Allan Westphall (Turnhout, 2013), 151-96, at 158, describes "an increasing concern to establish and promulgate the attribution of vernacular religious texts and books" beginning in the reign of Henry V, though Gillespie's examples tend to be lengthier than the minor works at issue here. On the vagaries of attribution in the Middle Ages, see Richard Sharpe, Titulus: Identifying Medieval Latin Texts: An Evidence-Based Approach, Brepols Essays in European Culture 3 (Turnhout, 2003).

${ }^{12}$ At least six examples are known to me:
}

1. A copy of Incendium owned by the Hampole nuns, recorded in Officium and Miracula of Richard Rolle of Hampole, ed. Reginald Woolley (London, 1919), 36.

2. A copy of the English Psalter also owned by the Hampole nuns, reported in BodL, MS Laud. misc. 286, fol. 1r-v; see The Psalter or the Psalms of David and Certain Canticles, with a Translation and Exposition in English, ed. H. R. Bramley (Oxford, 1884), 1-2.

3. A copy of either the Latin or English Psalter bequeathed to the Hampole nuns by Robert Est, will proved 26 January 1474/75; see Testamenta Eboracensia: A Selection of Wills from the Registry at York, 6 vols. (London, 1836-1902), 3:160.

4. A quire containing Judica bequeathed to Henry FitzHugh, founder of Syon Abbey, by Henry Scrope, Lord Masham, will proved 23 June 1415; see Susan Cavanaugh, "A Study of Books Privately Owned in England, 1300-1450” (PhD diss., University of Pennsylvania, 1980), 774.

5. A copy of Melos owned by the Syon brethren; see Syon Abbey, ed. Vincent Gillespie, with The Libraries of the Carthusians, ed. A. I. Doyle, Corpus of British Medieval Library Catalogues 9 (London, 2001), 228.

6. A copy of Incendium "quem sanctus Richardus de H. propria manu scripsit," purportedly used to correct the text in Cambridge, Emmanuel College, MS 35, where fol. 99r contains a marginal note with the quoted text; see Hanna, "Transmission," 314-15.

Speculum 94/4 (October 2019) 
to new and possibly unexpected texts led him to create an unusually messy manuscript. ${ }^{13}$ After beginning his work with a long stint of serial copying, the Bodley scribe adopted techniques now generally associated with miscellanies, writing Rolle's texts in six uneven booklets. ${ }^{14}$ Even among fascicular codices, however, Bodley is something of a shambles, and the scribe took unusual steps to bring order to its various parts. These efforts included the creation of notes-paper tags with instructions in the scribe's hand now stitched to different leaves in Bodley-meant to guide the production of a second anthology of Rolle's Latin, now Hereford, Cathedral Library, MS O.VIII.1, with Bodley serving as its exemplar. Along with other annotations and the material evidence of his rearranged quires, the apparently unique survival of these tags reveals how the scribe decided to order, reorder, and revise the contents of his collection to accommodate his changing understanding of Rolle as a writer.

The evidence of the Bodley scribe's activities is thus at once fragmentary and surprisingly abundant, and, to address this complex scene, this essay falls into four parts, alternating between close consideration of the material manufacture of these books and larger conceptual issues arising from them. The broad outlines of the Bodley scribe's work-how Bodley 861 was assembled, as well as the scribe's changing habits of copying - are presented first, emphasizing the scribe's unusual adaptation of the methods of booklet production. His inclusion of "derivative" and relatively rare minor writings then raises the question of his criteria for assessing the authenticity of the texts he encountered, and the second section argues that the Bodley scribe's recognition of Rolle's own work as a scribe led him to judge the authenticity of whole books rather than individual texts. The scribe's task was made more complicated by the need to send his booklets to the scribes producing Hereford O.VIII.1

\footnotetext{
${ }^{13}$ A disorder that is all the more pronounced in comparison to earlier medieval volumes of an author's collected writings, e.g., Cambridge, Corpus Christi College, MS 371, Eadmer's autograph collection, on which see R. W. Southern, Saint Anselm and His Biographer: A Study of Monastic Life and Thought, 1059-c. 1130 (Cambridge, UK, 1963), 367-74. On single-author manuscripts, see Erik Kwakkel, "Late Medieval Text Collections: A Codicological Typology Based on Single-Author Manuscripts," in Author, Reader, Book: Medieval Authorship in Theory and Practice, ed. Stephen Partridge and Erik Kwakkel (Toronto, 2012), 56-79. In Kwakkel's terms, Bodley 861 is a "type 3a" collection (see 67-69).

${ }^{14}$ On booklet production, see below. For the use of these procedures in compiling miscellanies, see especially The Whole Book: Cultural Perspectives on the Medieval Miscellany, ed. Stephen Nichols and Siegfried Wenzel (Ann Arbor, 1996); the special issue of the Yearbook of English Studies 33 (2003); as well as Julia Boffey and John Thompson, "Anthologies and Miscellanies: Production and Choice of Texts," in Book Production and Publishing in Britain, 1375-1475, ed. Jeremy Griffiths and Derek Pearsall (Cambridge, UK, 1989), 279-316. The association of these production techniques with miscellanies has continued in more recent work: Margaret Connolly, "Compiling the Book," in The Production of Books in England, 1350-1500, ed. Alexandra Gillespie and Daniel Wakelin, Cambridge Studies in Palaeography and Codicology 14 (Cambridge, UK, 2011), 129-49; Arthur Bahr, Fragments and Assemblages: Forming Compilations of Medieval London (Chicago, 2013); Bahr, "Miscellaneity and Variance in the Medieval Book," in The Medieval Manuscript Book: Cultural Approaches, ed. Michael Johnston and Michael Van Dussen, Cambridge Studies in Medieval Literature 94 (Cambridge, UK, 2015), 181-98; and Margaret Connolly and Raluca Radulescu, eds., Insular Books: Vernacular Manuscript Miscellanies in Late Medieval Britain, Proceedings of the British Academy 201 (Oxford, 2015).
}

Speculum 94/4 (October 2019) 
even as his own work of collection and copying continued, and the third section examines how he directed the making of this second copy from afar. Finally, all this evidence will be used to interpret previously unrecognized portraits of Rolle added by the Bodley scribe throughout his manuscript, registering his developing ideas about the author to whom he had devoted years of careful work.

Like the Tudor collectors described by Parkes, the Bodley scribe sought out "old books" as authoritative preservers of the past-in particular, he saw in these books a way to recover the activities of an author who had also been a scribe. ${ }^{15}$ His work reveals that, in addition to being their authors' earliest interpreters and, in their idiosyncratic choices of what and how to write, crucial contributors to the meaning of the texts they copied, medieval scribes could also be intelligent users of whole books. Aware of the different forces that shaped the selection and arrangement of writings and the physical structuring of codices, and sensitive to how successive generations of copying could cause newer books to diverge from older ones, scribes could make decisions about their work in light of a complex array of supratextual factors.

\section{Fascicular Copying and the Arrangement of Texts}

Like other manuscripts now bearing multiple Rollean works, Bodley 861 is the product of fascicular, or booklet, copying. As Hanna notes, working in booklets allowed for "open-ended collection procedures," letting scribes with "adventitious access" to Rolle's scattered texts assemble their volumes more easily in a series of discontinuous stints. ${ }^{16}$ In BodL, MS Laud. misc. 528, for example, another early fifteenth-century collection of the Hermit's Latin, at least four hands copied six texts in four (or perhaps five) fascicles. ${ }^{17}$ While the overall consistency of the texts' presentation suggests that a single patron may have meant them to come together, finally, in one volume, the copying of three works (Emendatio vitae, Judica me Deus, and Incendium amoris) each in their own discrete booklet (the first two of single quires) increases the likelihood that the exemplars for these works were found in different books, perhaps in the possession of different libraries or individual owners. Further, though the selections from Super Canticum and Contra amatores mundi on, respectively, fols. $24 \mathrm{r}-33 \mathrm{v}$ and $34 \mathrm{r}-41 \mathrm{v}$ are copied in a single hand, the second text begins at the start of a new quire, and Super Canticum may thus, at least at first, have represented yet another single-quire single-text booklet. The favoring of discrete booklets for individual works enabled each text to exist in a readable and durable state as soon as it was copied-its parts could be used independent of, and antecedent to, some possibly notional final whole. This approach, which allowed

\footnotetext{
${ }^{15}$ See the annotations in Bodley 861 , fols. $10 \mathrm{r}$ and $11 \mathrm{v}$, quoted above.

${ }^{16}$ Hanna, "Transmission," 325; see 324-27 on this trend in copying Rolle's works. The symptoms of copying in booklets are enumerated by P. R. Robinson, "The 'Booklet': A Self-Contained Unit in Composite Manuscripts," Codicologica 3 (1980): 46-69, expanded in the studies cited below. Most recently, see Patrick Andrist, Paul Canart, and Marilena Maniaci, La syntaxe du codex: Essai de codicologie structurale, Bibliologia 34 (Turnhout, 2013).

${ }^{17}$ For a description, see Hanna, Editing Medieval Texts, 148-51.
}

Speculum 94/4 (October 2019) 
scribes "to accommodate the arrival of new material, and to anticipate the failure of that material to arrive," was particularly well suited to the state of Rolle's uncollected corpus at the beginning of the fifteenth century. ${ }^{18}$

Compared to Laud. misc. 528, the scribe of Bodley 861 took advantage of only some of the benefits of booklet production. He did not begin his work with these procedures in mind, and even after adopting them he continued to copy texts serially and then subsequently (sometimes onerously) rearranged the papers making up his quires. This inconsistent and idiosyncratic use of fascicular methods, the source of much of the manuscript's messiness, is all the more remarkable in light of the scribe's unusual interest in the ordering of Rolle's major works, as well as in his evident curiosity concerning a number of shorter texts that he apparently considered attributable to the Hermit. Then again, his receptiveness to finding new Rollean texts, ones with which he was otherwise unfamiliar, may have been a major source of his problems. Though he may, in other words, have been among those scribes whom Alexandra Gillespie says copied in booklets because they "had in mind a composite manuscript of their own design," the sketchiness of his design-the degree to which he was uncertain of what texts he might find and of what his final product would therefore look like-posed a challenge even to the flexible collection procedures of fascicular copying. ${ }^{19}$

Of the six booklets that bear Bodley's twenty texts, the scribe's work almost certainly began with what is now Booklet II, by far the largest in the collection, with eight texts copied in six quires of six bifolia. (Fig. 1 gives the details of this quire structure.) Here, beginning with Melos amoris, the scribe has copied the Hermit's works continuously, leaving small gaps between texts and thereby allowing for the later supply of incipits and explicits and perhaps, in some cases, making it easier to locate the beginning of new works. ${ }^{20}$ The colophon concluding Judica (part A only) on fol. 102vb indicates that the scribe finished that text on 27 December 1409, the earliest in a series of dated annotations he supplied throughout the manuscript, providing a terminus ad quem for the booklet up to that point. ${ }^{21}$ Judica is followed by Incendium, copied on the next line but in a noticeably darker ink, implying a break in stints. It may be that, early in his journey, the scribe came upon a large collection of the Hermit's texts, whether in a single volume or a clutch of manuscripts, perhaps

\footnotetext{
${ }^{18}$ Alexandra Gillespie, “Medieval Books, Their Booklets, and Booklet Theory,” English Manuscript Studies 1100-1700 16 (2011): 1-29, at 9.

${ }^{19}$ Gillespie, "Booklet Theory," 6.

${ }^{20}$ Compare the space between texts on fols. $81 \mathrm{rb}(80 \mathrm{~mm})$ and $93 \mathrm{rb}(72 \mathrm{~mm})$ with fols. 90rb $(10 \mathrm{~mm})$ and $99 \mathrm{va}(22 \mathrm{~mm})$. In between, but with enough blank space to make their breaks easy to find, are fols. 100va $(40 \mathrm{~mm})$ and $101 \mathrm{vb}(42 \mathrm{~mm})$. This practice was relatively common: for another example, see Paris, Bibliothèque nationale de France (BnF), MS lat. 15700, described by Hanna, "Making Miscellaneous Manuscripts in Fifteenth-Century England: The Case of Sloane 2275," Journal of the Early Book Society 18 (2015): 1-28.

${ }^{21}$ The colophon reads, "Hec Ricardus Heremita dicit in libro quem habuit heremita de Tanfeld. Die veneris natali domini Sancti Iohannis 1409. Et nudus pedes 40 mill. ibat." Allen, Writings Ascribed, 28-30, entertains the unlikely possibility that the date refers not to the scribe's copying but to the hermit's miraculous walking (her interpretation of the ambiguous final phrase of the colophon, which could just as easily describe the unshod baptist). On the hermit of Tanfield, see Hanna, "Transmission," 321-22.
}

Speculum 94/4 (October 2019) 


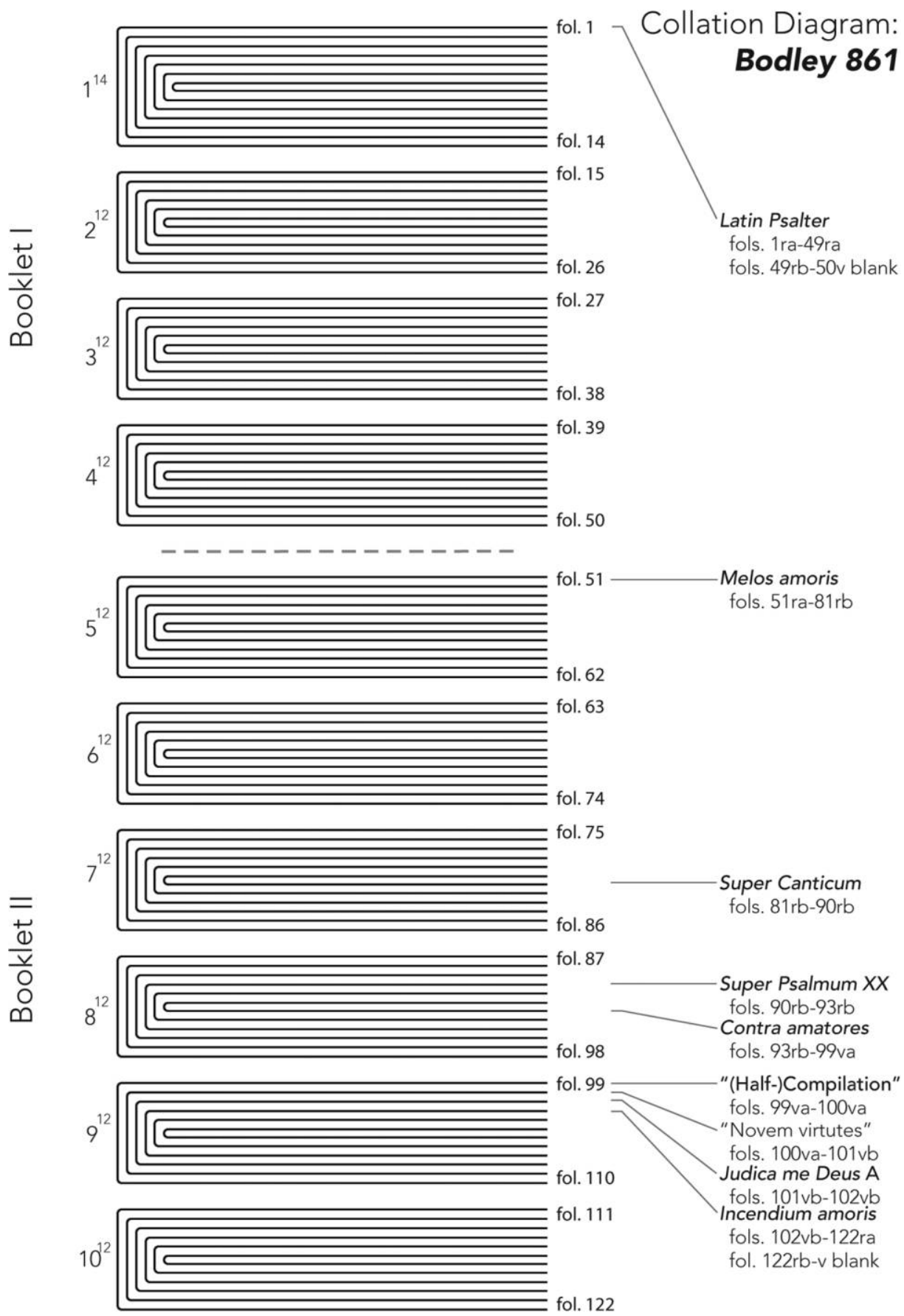

Fig. 1. The booklet and quire structure of Bodley 861. Boldface denotes works attributed to Rolle by Hope Emily Allen, Writings Ascribed to Richard Rolle, Hermit of Hampole (1926), and solid lines indicate where these texts begin in the manuscript; dotted horizontal lines between quires mark proposed booklet divisions. 


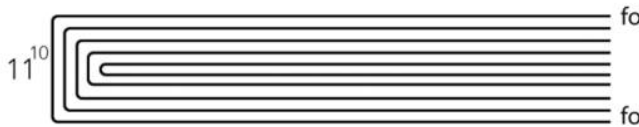

fol. 123
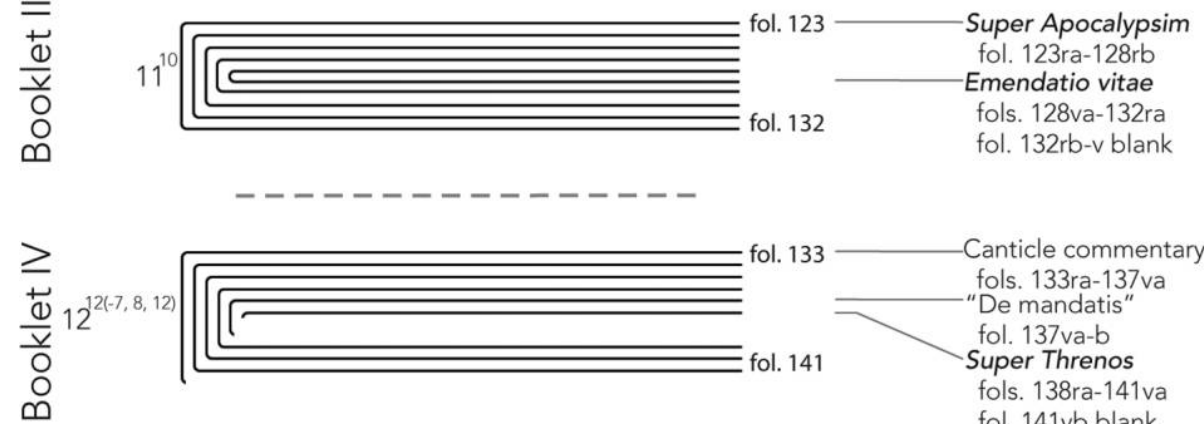

133

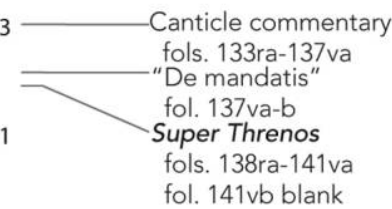

$>$
$\frac{1}{v}$
$\frac{1}{0}$
0
0

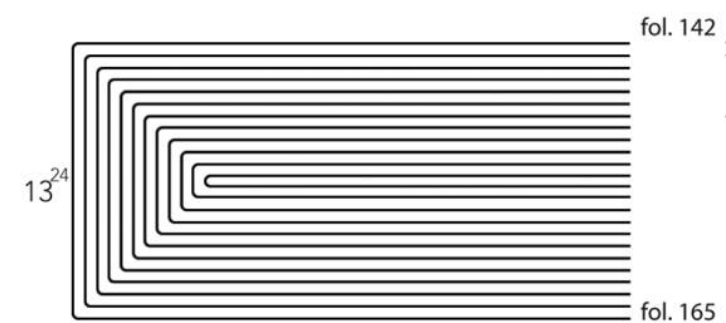

fol. 142

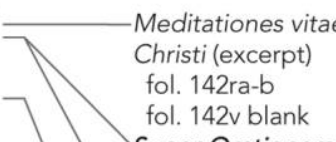

fol. 142v blank

Super Orationem

Dominicam

fol. 143ra-va

Super Symbolum

Apostolorum

fols. 143va-146va

fols. 146vb-147v blank Exposicio super

lecciones mortuorum

fols. 148ra-165ra

fol. $165 \mathrm{v}$ blank

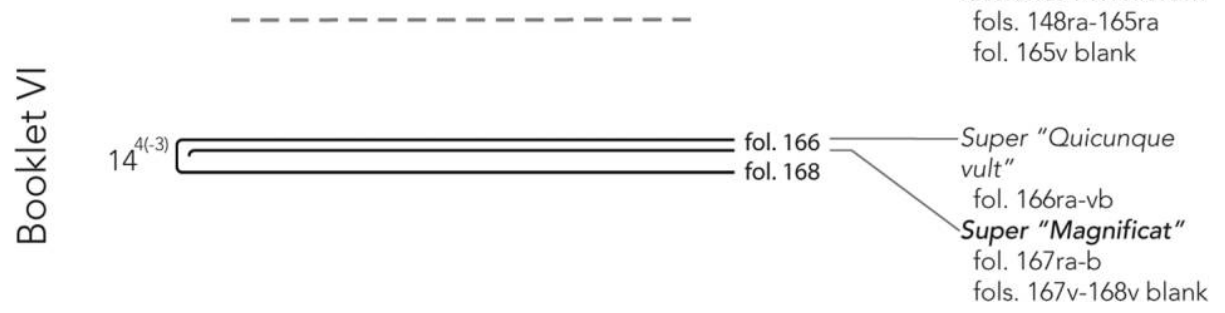

Fig. 1. (Continued)

associated with the "hermit of Tanfield" named in the dated Judica colophon. ${ }^{22} \mathrm{Al}-$ ternatively, the apparent continuity in ink in the booklet before Incendium could be effacing a greater number of stints. In either case, the booklet as a whole reflects the scribe's early effort at compiling Rolle's texts serially, not in fascicles, simply picking up with the next text when an exemplar became available. ${ }^{23}$ This approach did

\footnotetext{
${ }^{22}$ This hermit appears to have resided in the area now known as East Tanfield and West Tanfield, about $10 \mathrm{~km}$ north of Ripon. Note that one of the owners of a purported Rolle autograph, Henry FitzHugh, was Lord of West Tanfield (see above, n. 12). This hermit's copies of Rolle's works are discussed further in Kraebel, "Modes of Authorship and the Making of Medieval English Literature," in The Cambridge Handbook of Literary Authorship, ed. Ingo Berensmeyer, Gert Buelens, and Marysa Demoor (Cambridge, UK, 2019), 98-114.

${ }^{23}$ The possibility that the contents of Booklet II up to and including Judica were taken from a single Rollean collection is made doubtful by discrepancies in the contents of this booklet and the two extant
}

Speculum 94/4 (October 2019) 
not serve him poorly, and he was evidently able to obtain and copy exemplars of many of Rolle's major writings (Melos amoris, Super Canticum, Contra amatores, Incendium) and even some better-attested minor works (Super Psalmum XX, Judica), before he felt the need to change his procedures.

At the same time, this early booklet also offers some indication of why the scribe might have decided to abandon continuous copying in favor of a more flexible fascicular method. Between the last line of Judica and the first line of Incendium, the scribe inserted a rubricated incipit, "Incendium amoris hic incipit: habet xxii capitula," and, apparently at the same time, he added a note in the outer margin at this point in the text: "liber 3." A rubricated note in the lower margin of the otherwise blank fol. $122 \mathrm{v}$, after the conclusion of Incendium, is likely also part of this series of annotations: " 22 capitula cum cauda." As with the marginal note on fol. 10r of the Latin Psalter, these additions appear to reflect the scribe's consultation of a further copy of the text beyond his earlier exemplar. While, likely following that exemplar, the scribe had divided his copy of Incendium into forty-four unnumbered sections, each now beginning with a three-line initial supplied in blue ink, this second copy apparently either divided its text into twenty-two chapters or (more likely) its incipit erroneously read "xxii" for the more typical "xlii." ${ }^{24}$ More importantly, this second copy apparently contained multiple works by the Hermit, treating Incendium as the third text in a sequence of Rolleana. Further details of this arrangement are suggested by the incipit and explicit added to Contra amatores earlier in Booklet II. This incipit identifies that text as the "secundus liber Ricardi Heremite venerabilis Hampulis" (fol. 93rb), while the lengthier explicit (fol. 99va) reads:

De amore Dei contra amatores mundi secundum Ricardum Heremitam. Finis libri secundi, et tercius liber dicitur De incendio amoris, qui sic incipit: "Admirabar amplius quam enuncio quando siquidem sentiui cor meum primitus incalescere et igne estuare."

[On the Love of God against the Lovers of the World, by Richard Hermit. Here ends the second book, and the third book is called On the Fire of Love, which begins thus: "I was amazed more than I can say when I first felt my heart grow hot and burn with fire."]

copies of Judica A with which the Bodley scribe shared an exemplar, Dublin, Trinity College, MS 153 (also citing the Tanfield hermit in its explicit) and Cambridge, Emmanuel College, MS 35. On the affiliations of these copies, see An Edition of the "Judica me Deus" of Richard Rolle, ed. John Daly, Salzburg Studies in English Literature: Elizabethan and Renaissance Studies 92/14 (Salzburg, 1984), xxvii. Emmanuel 35 and Trinity 153 both lack Super Psalmum XX (found in Bodley's Booklet II), while Trinity 153 lacks Melos entirely and Emmanuel 35 contains only extracts of it—on which, see Richard Rolle, The "Melos amoris", ed. E. J. F. Arnould (Oxford, 1957), lxxv-lxxvii. Emmanuel 35 (but not Trinity 153) contains Super Orationem Dominicam (copied in Booklet V of Bodley), and both Emmanuel 35 and Trinity 153 contain Super mulierem fortem (lacking in Bodley). Hanna, "Transmission," 326, indicates that both Emmanuel 35 and Trinity 153 are fascicular assemblages, commenting on Emmanuel 35 more extensively at 314-17. For descriptions, see Marvin Colker, Descriptive Catalogue of the Medieval and Renaissance Latin Manuscripts, Trinity College Library, Dublin, 2 vols. (Aldershot, 1991), 1:270-71; and Michael Sargent, James Grenehalgh as Textual Critic, 2 vols., Analecta Cartusiana 85, (Salzburg, 1984), 2:478-87.

${ }^{24}$ Bodley's forty-four sections correspond to the typical prologue plus forty-two chapters, with the final chapter divided in Bodley into two sections: see The "Incendium amoris" of Richard Rolle of Hampole, ed. Margaret Deanesly (Manchester, 1915), 35-36.

Speculum 94/4 (October 2019) 
These rubrics are copied in a more formal script, but, based on other variations in his hand, they are almost certainly the work of the manuscript's main scribe. ${ }^{25}$ According to his newly discovered book, Incendium should follow immediately after Contra amatores, but since this sequence became known to the scribe after he had copied several texts between them, he could only signal it in these colophons, including a quotation of Incendium's opening to make the gesture forward as clear as possible. ${ }^{26}$ The details of this arrangement of the Hermit's works will be discussed below, but it seems likely that the Bodley scribe's decision to switch to booklet production was encouraged by his inability to rearrange his continuously copied texts to reflect what he took to be a significant ordering.

Unfortunately, only two other booklets in Bodley contain annotations indicating the dates on which they were copied, making it impossible to reconstruct the scribe's progress with absolute certainty. Still, it seems most likely that the move from serial to booklet production represents a single and decisive shift in his procedure. ${ }^{27}$ The scribe appears subsequently to have worked in a way that more closely resembles the approach seen in Laud. misc. 528, with individual texts copied at the start of new booklets, which are thereby left open to reordering at some later date. In its final form, however, this one-to-one correspondence of fascicles and texts is only preserved in the four quires of Bodley's Booklet I, where the scribe copied the Latin Psalter, by far the Hermit's longest Latin work. More commonly, he can be found beginning new booklets to bear new texts and then supplementing these initial stints with further texts discovered in other sources. This approach, resulting in what Erik Kwakkel calls "extended production units," is certainly not uncommon in fascicular copying, but the Bodley scribe's penchant for rearranging the sheets that made up his quires has led to several unusual configurations, in part effacing the process by which his booklets were made. ${ }^{28}$ In Booklets IV and V, in particular, the scribe has begun with fresh quires apparently meant to bear individual texts, and the subsequent discovery of further writings has led him to extend these units with the new material. In both cases, however, the scribe goes on to modify the configuration

\footnotetext{
${ }^{25}$ The more formal script of these rubrics also appears in the explicit to the Exposicio on fol. 165ra, where, beginning with his normal text script, the Bodley scribe gradually increases the size and angularity of the text as he writes.

${ }^{26}$ Note, however, that in copying the explicit of Contra amatores, the scribe dropped some text from Incendium's opening, between the words "et igne" in the quotation above. This dropped text corresponds precisely to the third line of Incendium in Bodley 861 , fol. $102 \mathrm{vb}$, indicating that the scribe was copying this material, though with a case of eye skip, from this later point in the manuscript.

${ }^{27}$ In this regard, the Bodley scribe bears comparison to scribe B of the Hengwrt Canterbury Tales (Aberystwyth, National Library of Wales, MS Peniarth 392D), who began his work with an attempt at serial copying, yielding what is now that manuscript's fourth booklet, before shifting to fascicular production. See A. I. Doyle and M. B. Parkes, "Construction of the Volume," in Geoffrey Chaucer, The Canterbury Tales: A Facsimile and Transcription of the Hengwrt Manuscript, with Variants from the Ellesmere Chancer, ed. Paul Ruggiers, A Variorum Edition of the Works of Geoffrey Chaucer 1 (Norman, OK, 1979), xxii-xxxiii; Ralph Hanna, Introducing English Medieval Book History: Manuscripts, Their Producers, and Their Readers (Liverpool, 2015), 155-65.

${ }^{28}$ Compare the typical use of "extended production units" described by Erik Kwakkel, "Towards a Terminology for the Analysis of Composite Manuscripts," Gazette du livre médiéval 41 (2002): 1219 , at 14 .
} 
of these quires, and the result is a set of fascicles that, at least at first glance, appear to defy the norms of booklet production.

In fascicular copying, longer texts-the kind of major works that would first attract the attention of a scribe or patron-typically appear at the start of a booklet, with shorter material added on the remaining leaves of the booklet's final quire. ${ }^{29}$ Booklet $\mathrm{V}$, in contrast, begins with three short texts, the first of which is not by Rolle but rather an excerpt from the Meditationes vitae Christi, reserving the longest work, the Hermit's Exposicio super nouem lecciones mortuorum, for the end of the gathering (see Fig. 1). The blank folios after the Meditationes and immediately before the Exposicio are also unusual, the sort of leftover space that is more likely to appear at the end of a booklet. ${ }^{30}$ This atypical arrangement could be explained, however, if the booklet was first produced in the scribe's more common quires of twelve leaves, as follows:

\begin{tabular}{lll}
\hline \hline Quire A & fols. 1r-12v & $\begin{array}{c}\text { Rolle, Exposicio super nouem lecciones } \\
\text { mortuorum (beginning) } \\
\text { Rolle, Exposicio super nouem lecciones } \\
\text { Quire B }\end{array}$ \\
& fols. 1r-6r & blank \\
& fol. $6 \mathrm{v}$ & Meditationes vitae Christi (excerpt) \\
& fol. $7 \mathrm{r}$ & blank \\
& fol. $7 \mathrm{v}$ & Rolle, Super Orationem Dominicam \\
& fol. $8 \mathrm{r}-\mathrm{v}$ & Rolle, Super Symbolum Apostolorum \\
& fols. $8 \mathrm{v}-11 \mathrm{v}$ & blank \\
\hline
\end{tabular}

The Hermit's commentary on the Lessons of the Dead would thus fill quire A and the first half of quire B, with blanks positioned such that two of the three short texts in the remainder of quire B could begin at the top of a recto. ${ }^{31}$ With this arrangement, the booklet would appear unremarkable, beginning with a long work that is widely attested and therefore presumably easy to locate, followed by a shorter piece of unrelated filler and then two less common Rollean works, likely located only later and in a different manuscript. ${ }^{32}$ (Additionally, since the conclusion of the

\footnotetext{
${ }^{29}$ Robinson, "Booklet," 48 (no. 10). Such materials, called "filler" in Anglo-American scholarship, are referred to as "guest texts" by J. Peter Gumbert, "Codicological Units: Towards a Terminology for the Stratigraphy of the Non-Homogenous Codex," Segno e testo 2 (2004): 17-42, at 30.

${ }^{30}$ Robinson, "Booklet," 48 (no. 9).

${ }^{31}$ In the other extant copies of Super Symbolum, that text is immediately preceded by Super Orationem, suggesting that these two works were likely treated as a discrete unit in Bodley's exemplar: see Allen, Writings Ascribed, 158. To the other six copies of this pairing known to Allen, I can add a seventh: Urbana, University of Illinois Urbana-Champaign, MS 145, fols. 1r-12v, described in Kraebel, "Latin Manuscripts of Richard Rolle at the University of Illinois," JEGP 119 (2020): forthcoming.

${ }^{32}$ Malcolm Moyes, Richard Rolle's "Expositio super novem lectiones mortuorum": An Introduction and Contribution towards a Critical Edition, 2 vols. (Salzburg, 1988), 2:1-103, catalogs fortytwo complete or near-complete manuscript copies of the text, to which five further witnesses should be added: Cambridge, Fitzwilliam Museum, MS 356, fols. 127v-202r; Dublin, Trinity College, MS 191, fols. 95r-127v; New Haven, Beinecke Library, MS Osborn a29 (complete); and Princeton, University Library, MS Garrett 87, fols. 1r-17v (all listed in A. I. Doyle, Hope Allen's "Writings Ascribed to Richard Rolle": A Corrected List of Copies, ed. and extended by Ralph Hanna, Publications of the Journal of Medieval Latin 13 [Turnhout, 2019], 10-11); as well as BodL, MS Rawlinson C. 348,
}

Speculum 94/4 (October 2019) 
Exposicio required less than half a column on the recto of its final folio, it is possible that the loose bifolium with the Meditationes excerpt already copied on it was simply folded in the other direction and supplied to do the job. ${ }^{33}$ If fols. 7-12 of quire B (i.e., the quire's second half) were then folded around the entirety of quire $\mathrm{A}$, the result would be a single gathering of twenty-four folios in the order $\mathrm{B} 7-\mathrm{B} 12 / \mathrm{A} 1-\mathrm{A} 12 / \mathrm{B} 1-\mathrm{B} 6$, with the contents precisely matching the current state of the booklet.

A second example of this kind of codicological inversion (what Hanna calls "folding in reverse") appears in Bodley's much smaller Booklet IV, though this case is made more complicated by the excision of what were, presumably, blank leaves like those remaining in Booklet $\mathrm{V}$ (see Fig. 1). ${ }^{34}$ Though it appears in the middle of this single-quire booklet, the short text De mandatis on fol. $137 \mathrm{v}$ is a typical example of filler copied in blank spaces remaining at the end of booklets. ${ }^{35}$ The likelihood that this brief bit of pastoralia was the last work to be copied in the booklet is confirmed by two of the scribe's dated annotations: the first, in the explicit of the Song commentary (fol. 137va), indicates that the copying of that text concluded on $5 \mathrm{Au}$ gust 1411, while the second, a marginal annotation toward the end of Rolle's Super Threnos Jeremiae (fol. 141r), dates at least that page of the text to 3 May $1410 .^{36}$ (These dates indicate that Booklet IV was begun before and completed after the entire stint of copying the Latin Psalter in Booklet I, dated by a series of annotations from 29 September 1410 to 13 May 1411.) ${ }^{37}$ Of course, the arrangement of Booklet IV could be explained in many ways, but the simplest seems to be the following. The scribe began by copying Super Threnos in a fresh quire, with that text filling three complete folios and concluding on the verso of a fourth. This would have produced a gathering of four bifolia with the second half completely blank, and sometime after this stint (but before beginning the Song commentary) he seems to have trimmed away the final (eighth) folio, leaving only a stub. (At this point, then, the gathering was in the order fols. 138-141 + 134-136 + stub.) More than a year later, the scribe came upon the Song commentary and decided that he wanted it in the same quire as Super Threnos, and, further, that he wanted it to begin the quire. $\mathrm{He}$ therefore inverted the three intact bifolia from his earlier stint, nested in the middle the singleton on which Super Threnos began, and added a fresh bifolium to the

\footnotetext{
fols. 16r-38v (not listed in Doyle and Hanna's supplement). Of the other manuscripts of Super Orationem and Super Symbolum reported by Allen, Writings Ascribed, 156-58, only the large Rolle anthology Oxford, Corpus Christi College, MS 193 (discussed below), also contains the Exposicio-and, in Corpus 193, copied serially, three other texts come between the end of the Exposicio (fol. 135r) and the start of Super Orationem (fol. 160r).

${ }^{33}$ Perhaps explaining the inclusion of model alphabets and a probatio pennae on fol. 142va.

${ }^{34}$ Ralph Hanna, Pursuing History: Middle English Manuscripts and Their Texts (Stanford, 1996), 25. Note that at least some of these excisions, the sort of loss that is typically associated with postmedieval damage to the books, are best explained as part of the scribe's own manipulation of his papers.

${ }^{35}$ This impression is supported by its awkward presentation on the page: De mandatis begins at the top of the right column on fol. 137v (23 lines), then, after reaching the point at which the Song commentary ends in the left column, it continues in long lines across the width of the page (29 lines), before the last portion is finally written in what remains of the left and then the right columns ( 28 and 15 lines, respectively).

${ }^{36}$ Allen, Writings Ascribed, 32; Hanna, Editing Medieval Texts, 145.

${ }^{37}$ Allen, Writings Ascribed, 24-25; Hanna, Editing Medieval Texts, 142.
}

Speculum 94/4 (October 2019) 
outside of the gathering. He could then copy the Song commentary on the four blank folios with which the quire now began-but this space proved insufficient for the job, and so he inserted a blank singleton (now fol. 137) to receive the rest of the text. He subsequently trimmed the quire's final (presumably blank) folio and copied the short anonymous work on the Commandments in the space that remained on fol. $137 \mathrm{v}$.

This scribe's willingness to rearrange his papers may help to explain the state of another quire in Bodley 861, though in a way that creates complexity in what appears to be a straightforward situation. Booklet III is a quire of five bifolia, beginning with Rolle's poorly attested and incomplete commentary on the Apocalypse (ending at Apoc. 6.2), followed by the scribe's abortive attempt to copy his most widely circulating work, Emendatio vitae, abandoned after filling little more than a single column on fol. 128v. (Though it is still left incomplete, most of the remainder of Emendatio has been supplied by later scribes. ${ }^{38}$ ) Describing this quire, Hanna follows Hope Emily Allen and concludes that its current state reflects the order in which the texts were copied. ${ }^{39}$ Following typical procedures for "extended production units," in this scenario the scribe has simply supplemented an earlier stint (Super Apocalypsim) with new material (Emendatio) when it became available, breaking off when he realized "that he need not waste much time on a text that was almost ubiquitously disseminated." 40 In light of the practices described above, however, it is more likely that the scribe began to copy (and stopped) Emendatio before his work on Super Apocalypsim, and that, sometime later, as he neared the end of his stint with the commentary, he reversed the mostly blank Emendatio bifolium and used it to bear the conclusion of the new text. (This would match his use, noted above, of the reversed Meditationes bifolium for the conclusion of the Exposicio.) If he had been able to fit the end of Super Apocalypsim on the first leaf of this bifolium, he would have produced (as in Booklets IV and V) a quire whose second half was completely blank (apart from the earlier scrap material). As it happens, he underestimated the amount of space he needed, and the Apocalypse commentary now concludes after filling the first column and two lines of the second on the middle bifolium's third leaf (fol. 128r). ${ }^{41}$

Though imperfectly executed, Booklet III appears to present at once the scribe's attempt to conserve his resources, reusing another mostly blank sheet to bear the end of a new work, and his willingness to produce waste, with four folios at the end of the quire left untouched until filled out by later scribes. Had he more fully prioritized conservation, he could simply have produced a smaller quire, perhaps of three or four bifolia, for Super Apocalypsim. ${ }^{42}$ He could, of course, be following standard procedures for booklet production, anticipating "the arrival of new

\footnotetext{
${ }^{38}$ See "De emendatione vitae": Eine kritische Ausgabe des lateinischen Textes von Richard Rolle; mit einer Übersetzung ins Deutsche und Untersuchungen zu den lateinischen und englischen Handschriften, ed. Rüdiger Spahl, Super Alta Perennis 6 (Bonn, 2009), 30-31 and 90-96.

${ }^{39}$ Hanna, Editing Medieval Texts, 144-45 and 147; cf. Allen, Writings Ascribed, 31-32.

${ }^{40}$ Hanna, Editing Medieval Texts, 147.

${ }^{41}$ Hanna, Pursuing History, 27, notes that while casting off "would become a commonplace necessity in producing printed books," it was comparatively "difficult . . . in manuscript culture."

${ }^{42}$ Compare the inconsistent number of bifolia making up quires 1-3 of Laud. misc. 528, discussed above: see Hanna, Editing Medieval Texts, 149.
}

Speculum 94/4 (October 2019) 
material" that could be copied on these blank leaves and, if necessary, continued in an additional quire. ${ }^{43}$ But, taken together with Booklets IV and V, the scribe's approach in Booklet III indicates that he sought to keep his fascicles open not only to the discovery of new material, but also to the possibility that such material ought to be presented before what he had already copied in a quire. In all three booklets, by at least attempting to leave the back halves of quires blank, he adopted an approach that would allow for the reversal of the quires and the reordering of their contents. Compared to the method favored in Laud. misc. 528, this practice is clearly cumbersome and imprecise, illustrated by Booklet IV's excised leaves and what seems to be the failed casting off in Booklet III. But the flexible arrangement of texts that motivated the scribe's unusual approach to booklet production is consistent with his interest not just in collecting Rolle's texts, but also assembling them in a particular (and, as we will see below, sometimes significant) order. ${ }^{44}$

Offering a "basic definition of the booklet" that insists on "the lack of overall planning of a codex until late in production," Hanna emphasizes that booklets were "separately conceived," an account that has recently been endorsed by J. P. Gumbert, who argues that "codicological units" (his term for booklets) are distinguished by a "unity of purpose." 45 It is clear enough that the Bodley scribe conceived of his booklets as discrete pieces that could later be reshuffled, but his approach also works against this notion of each booklet's conceptual distinctiveness-that any given booklet could in isolation be self-sufficient-since the serial copying of his earliest stint indicates that he was always working towards a definite final product, a massive single-author anthology. ${ }^{46}$ To adapt Hanna's terms, these booklets were, from the

\footnotetext{
${ }^{43}$ Gillespie, "Booklet Theory," 9.

${ }^{44}$ For another example of this procedure, see John Thompson, "The Compiler in Action: Robert Thornton and the 'Thornton Romances' in Lincoln Cathedral MS 91," in Manuscripts and Readers in Fifteenth-Century England: The Literary Implications of Manuscript Study; Essays from the 1981 Conference at the University of York, ed. Derek Pearsall (Cambridge, UK, 1983), 119-24. Another reversal is identified in the same book by George Keiser, “'To Knawe God Almyghtyn': Robert Thornton's Devotional Book," in Spätmittelalterliche geistliche Literatur in der Nationalsprache, ed. James Hogg, 2 vols., Analecta Cartusiana 106 (Salzburg, 1983-84), 2:103-29. See too Hanna, Pursuing History, 25-27. For more recent discussions of this volume, see Robert Thornton and His Books: Essays on the Lincoln and London Thornton Manuscripts, ed. Susanna Fein and Michael Johnston (York, UK, 2014).

${ }^{45}$ Hanna, Pursuing History, 29 and 31; Gumbert, "Codicological Units," 24. At least in part, this insistence on potential conceptual distinctiveness seems to be a vestige of Robinson's initial discussion of booklets as smaller units limply bound in parchment, a failure to distinguish what Hanna calls the "booklet as purchased" and the "booklet as produced" (or, in Kwakkel's terms, "usage units" and "production units"). The conflation of these categories (and the occasional trouble of distinguishing between them) is discussed further by Gillespie, "Booklet Theory."

${ }^{46}$ In this case, Gumbert's "codicological unit" may seem like a better descriptor of Bodley 861 in its entirety, insofar as he defines such units as "a discrete number of quires, worked in a single operation and containing a complete text or set of texts," and especially since he notes that a "single operation" can be prolonged and undertaken in "more than one place" ("Codicological Units," 23). Yet he also affirms Birger Munk Olsen's definition of the codicological unit as "the smallest unit which can have existed separately, because the text end coincides with a quire end" (25, emphasis added), and in this case the codicological units of Bodley 861 must be identified with the different booklets described above. These inconsistencies appear to derive from Gumbert's assumption that medieval scribes tended to work with a clear and definite purpose in mind, and he does not allow for sufficient openness to changing conceptions of the scribe's project.
}

Speculum 94/4 (October 2019) 
outset, in the process of being "codicized" or assembled into a book: they were always in a transitional state, discrete units fitting into some larger whole. ${ }^{47}$ It is that imagined volume, rather than these individual parts, that best reflects the scribe's "unity of purpose," and he apparently worked in booklets-routinely adopting some of the most complexly provisional methods of fascicular production-as a way of at once realizing that plan and also deferring any final decisions about the arrangement of his texts. Copying in booklets allowed this scribe to work toward the larger goal of reassembling Rolle's corpus, all the while remaining open to the possibility that he would locate new texts and more authoritative witnesses of works he had already copied.

\section{Scribal Authorship AND the Authority of Books}

His openness to new evidence allowed the Bodley scribe to produce good copies of Rolle's major texts, comparing newly found witnesses to his earlier work and making what he judged to be appropriate corrections.$^{48}$ It also allowed him to preserve some of the Hermit's minor and most poorly attested writings, and the resulting volume is one of a small number of surviving copies for several of Rolle's short Latin works. Yet being able to locate texts is not quite the same thing as being able to identify them as the work of a specific author, and at some point, though he did not define Rolle's corpus prospectively, this scribe would have to decide whether texts were or were not the work of his author. Especially in the case of the minor writings, the basis on which the scribe made his attributions is not immediately clear. These are all texts assigned by Watson to an early stage in Rolle's career, what he calls "deliberately tentative" pieces, ones in which the "assertive yet exemplary persona" characteristic of his later works was not yet fully developed, and, though Allen can sometimes point to isolated passages of Rolle's characteristic alliteration or mystical enthusiasm, external evidence would still be crucial to their attribution, in the fifteenth century and more recently. ${ }^{49}$ It is, of course, possible that the scribe deferred to claims made by the owners of his exemplars. Yet, especially in light of the note on fol. 10r suggesting his preference for old books (quoted above), it is much more likely that

\footnotetext{
${ }^{47}$ Hanna, Pursuing History, 25, identifies "codicizing” as a phase in the history of a booklet when it is especially likely to be manipulated or otherwise reworked.

${ }^{48}$ At the opening of Incendium on fol. $102 \mathrm{vb}$, for example, "exteriori" is corrected to "ex interiori" and, a few lines later, "concupiam" is corrected to "concupiscencia" (cf. Rolle, Incendium, ed. Deanesly, 145, lines 7 and 9). Both these corrections are made in red ink matching the added incipit and "liber 3," apparently confirming that they reflect the scribe's comparison of his text to a second exemplar. Even more definitive is the evidence of the Exposicio, since numerous words and phrases omitted in Oxford, Corpus Christi College, MS 193, Bodley's congener for that text (discussed below), are later added interlinearly in Bodley by the main scribe: e.g., "culpa occupati hiis aliis miseriis" (Bodley fol. 150vb; Moyes, Introduction and Contribution, 2:150, lines 13-14); "minus" (fol. 152va; Moyes, 2:166, line 10); "habet" and "videt" (fol. 153ra; Moyes, 2:170, line 13, and 171, line 6). More evidence of interlinear correction is apparent in Bodley's copy of Contra amatores. For discussion of such practices, see Daniel Wakelin, Scribal Correction and Literarv Craft: English Manuscripts 13751510, Cambridge Studies in Medieval Literature 91 (Cambridge, UK, 2014).

${ }^{49}$ Watson, Invention of Authority, 97 and 7. Similar dependence on external evidence may be seen, for example, in the case of Chaucer's shorter poems: see Seth Lerer, Chancer and His Readers: Imagining the Author in Late-Medieval England (Princeton, 1993), 117-46.
}

Speculum 94/4 (October 2019) 
his own judgments of those exemplars contributed, importantly, to his decisions about what to copy.

The most obvious source potentially influencing the scribe's decision to include a given work as "genuine Rolle" is, of course, an attribution made in his exemplar. For at least two reasons, however, this evidence is surprisingly far from straightforward. First, if a scribe has decided that a work should be attributed to an author, he can (regardless of what he has found in his exemplar) simply assert that attribution in his own colophon, and the only way to be confident that he is replicating peritextual material from his exemplar is either by identifying that exemplar among the extant copies of a text (which cannot be done for any of the works in Bodley) or, less securely, by noting the persistence of such attributions in the other surviving manuscripts of the text. Between the paired Super Orationem and Super Symbolum, for example, two works Watson considers "least characteristic of Rolle's later writing," the Bodley scribe has included a short incipit asserting the authorship of both commentaries, "Idem R. super Simbolum" (fol. 143va), and similar attributions are made in most surviving copies of these paired works. ${ }^{50}$ But, second, though the scribe was therefore most likely preserving his exemplar's claim of authenticity in the case of these texts, in general he makes few assertions of authorship throughout the volume: nowhere, for example, does he attribute Melos, Super Apocalypsim, or Super Threnos to Rolle, and the Latin Psalter is only identified as the "glosa Ricardi" in the marginal notes on fols. $10 \mathrm{r}$ and $11 \mathrm{v} .{ }^{51}$ With the exception of the Marian excerpt from the Meditationes, which may have been used as a matter of convenience to bear the end of the Exposicio, the scribe's decision to include a text in his volume should therefore be taken (at least provisionally) as an assertion of authenticity, and the absence of an overt attribution in Bodley is as likely to reflect this scribe's particular habits as it is to reveal anything about his exemplars.

Apart from Super Orationem and Super Symbolum, the minor exegetical works outside Booklet II fall into this last category-they all lack overt attributions in Bodley, and the record of their attribution in other manuscripts is less consistent. In these cases, though it is still possible that the Bodley scribe simply chose not to copy an attribution present in his exemplar, the status of the exemplar itself may have been the most important factor informing his decision to copy. Super Apocalypsim, for example, is among the commentaries Watson assigns to an early phase in the Hermit's career, derivative works which "closely reflect the language and preoccupations of their sources." ${ }^{52}$ It survives only in Bodley 861, the copy derived from it (Hereford, Cathedral Library, MS O.VIII.1, discussed below), and another anthology of Rolle's Latin, now Oxford, Corpus Christi College, MS 193 + London, British

\footnotetext{
${ }^{50}$ Watson, Invention of Authority, 97; on the attributions, see Allen, Writings Ascribed, 156-58.

${ }^{51}$ This habit may be part of his larger preference to omit peritextual material found in his exemplars. In the Exposicio, for example, the Bodley scribe drops chapter headings preserved in his congener, Corpus 193, and the same headings are found in other closely related copies, including Cambridge, University Library, MS Ii.1.26, and BodL, MS Hatton 86.

${ }^{52}$ Watson, Invention of Authority, 97, 99-103, and 277-78. Watson does go on to say that these works are "not without distinctiveness" (97), and Allen, Writings Ascribed, 152-55, collects passages in Super Apocalypsim reflecting Rolle's "individual experience, doctrine, and style." In the case of Super Apocalypsim, Rolle's source has been identified as a commentary attributed to Anselm of Laon, printed in PL 162:1499-1586.
}

Speculum 94/4 (October 2019) 
Library (BL), MS Cotton Tiberius A. xv, fols. 181r-194v. The damage to the Cotton fragment, where the commentary occurs (fols. 181r-189v), makes the question of its attribution in that manuscript unclear. ${ }^{53}$ Nicole Marzac argues persuasively that Cotton and Bodley shared a common exemplar for Super Apocalypsim, a copy that she believes to be either an autograph or not far removed from one. ${ }^{54}$ The only other attested medieval copy, recorded in the library of the Syon brethren, presented Super Apocalypsim following after Incendium, and-since there is no reason to believe that many more copies of this incomplete work ever existed-this lost book may reflect the text's arrangement in the exemplar used by the scribes of the bigger anthologies. ${ }^{55}$ If that were the case, collocation with the major work could have been an important factor in judging the commentary's authenticity. Indeed, such collocation could also help to explain the Bodley scribe's inclusion of the similarly derivative Super Threnos and the anonymous commentary on the Song of Songs, both of a similar length to Super Apocalypsim and therefore perhaps more likely to circulate with another work than on their own. ${ }^{56}$ If he found these "uncharacteristic" writings paired with the major works he had already copied, the scribe may have been more likely to judge them to be Rolle's as well.

The status of nearby texts would seem to be even more important for the shorter examples of the Hermit's exegesis copied without overt attributions in Booklet VI, the commentaries Super Magnificat and Super Quicunque vult. Though it is still possible that the Bodley scribe found Super Apocalypsim and Super Threnos circulating independently in small booklets, these last two works are almost certainly

\footnotetext{
${ }^{53}$ On this anthology, see Hanna, "Transmission," 329-30 (though I come to different conclusions regarding the relationship between Corpus 193/Cotton Tiberius A. xv and Bodley: see below), and Rodney Thomson, A Descriptive Catalogue of the Medieval Manuscripts of Corpus Christi College, Oxford (Cambridge, UK, 2011), 96-97. Based on the Lacy coat of arms on fol. 1r, Corpus 193 was produced in the area of Pontefract, about $20 \mathrm{~km}$ north of Hampole, and a note on the front pastedown identifies it as a "liber fratris Iohannis Honton monachi Ebor.," i.e., a monk of Saint Mary's York. On its later ownership, see Andrew Watson, The Manuscripts of Henry Savile of Banke (London, 1969), 29 (no. 56) and 80 (no. 16).

${ }^{54}$ Richard Rolle de Hampole (1300-1349): "Tractatus super Apocalypsim"; Texte critique avec traduction et commentaire, ed. Nicole Marzac (Paris, 1968), 85-86.

${ }^{55}$ Recorded in the Syon catalogue as M. 96: see Syon Abbey, ed. Gillespie, 251. Then again, this manuscript could have been a fascicular job like Laud. misc. 528, with Super Apocalypsim copied in a discrete and previously independent booklet. The potential importance of collocation is not limited to works in Booklets III-VI. Super Psalmum XX, in Booklet II, for example, now only survives alongside other Rolle texts: see The Tractatus super Psalmum vicesimum of Richard Rolle of Hampole, ed. James C. Dolan, Texts and Studies in Religion 57 (Lewiston, ME, 1991), xxxiii-xl.

${ }^{56}$ Super Threnos likewise survives in too few English witnesses to allow for confidence that the Bodley scribe, who does not include an attribution in his copy, found it explicitly attributed to the Hermit: see Allen, Writings Ascribed, 150. Though this commentary is only preserved in larger Rolle anthologies, its presentation immediately after the Exposicio in Corpus 193 may indicate that it was copied from a volume containing these two texts in this order, and, quite tentatively, Bodley 861 may support this arrangement. At some point after he finished copying the Exposicio, the Bodley scribe returned and wrote, in a lighter ink on fol. 165ra, four verses that conclude that text in most good copies ("Talentum traditum timens ..."; see Moyes, 2:283), followed immediately (in the same lighter ink) by an excerpt from Super Threnos, labeled "Trenorum Geremie in glosa," potentially supporting the collocation of these texts in some other manuscript. For the excerpted passage, beginning “Malus est amor," see D. Richardi Pampolitani Anglosaxonis Eremitae ... in Psalterium Dauidicum . . enarratio, ed. Johannes Faber (Cologne, 1536), sig. Z5v. The attribution of the commentary on the Song of Songs is discussed further below.
}

Speculum 94/4 (October 2019) 
too short to have been preserved on their own. As further evidence of the scribe's desire to defer the final ordering of his texts, each of these commentaries appears to have been copied in Bodley on the first folios of otherwise blank bifolia-the shorter Super Magnificat not even filling two columns on fol. 167r, while the scribe made some effort to ensure that Super Quicunque vult would conclude at the foot of fol. 166vb-and only later did he decide to crop the conjoint leaf of one and nest it inside the other (see Fig. 1). ${ }^{57}$

This brevity is important, and, before addressing the Bodley scribe's decision to copy these works, it will be useful to reconsider Watson's positioning of them in the larger arc of Rolle's career. For Super Magnificat, Watson's dating depends entirely on internal evidence: the commentary includes some thematic concerns (especially a focus on the elect) that he associates with the Hermit's "mature biblical expositions and treatises," but it is also stylistically "monotonous," representing "only the crudest version of Rolle's mature thought." 58 Rather than being a symptom of its author's immaturity (or, indeed, senility), however, this repetitiveness and crudity may be explained better if the work is considered filler, originating in Rolle's relatively informal attempt to fill a specific amount of space left after copying another text in one of what Hanna calls his "dispersed autographs directed to specific known audiences." 59 The commentary's incidental quality is suggested immediately in its offhanded opening (fol. 166ra): "Istum psalmum benedicte Virginis dicimus canticum, tamen in persona veri amatoris Christi non incongrue illum pro magna parte possumus exponere" (We call this psalm the song of the blessed Virgin, but we can expound the greater part of it, not inappropriately, in the persona of Christ's true lover). Though Watson reads this as a bold declaration "that Rolle intends to interpret the text in an original way," its various qualifications ("non incongrue," "pro magna parte") seem instead to characterize the work as something of an afterthought. ${ }^{60}$ This sense continues in, for example, the Hermit's gloss (fol. 166ra) of the phrase "And my spirit has rejoiced in God my savior" (Luke 1.47) as describing someone

cui pro amoris magnitudine nichil transitorium placere potest, cui omnis carnalis concupiscencia, omnia vana mundi gaudia vilescunt, quem nulla diuiciarum copia extollat nec ulla inopia vel aduersitas minuit, sed pro Christo languens, in Christum sciciens, semper ad illam eterne claritatis visionem terrena queque contempnendo suspirat.

[who, on account of the great intensity of his love, can find pleasure in nothing transitory, who spurns every fleshly desire and all the empty joys of the world, who does not value an abundance of riches and is not diminished by any need or adversity, but rather languishing for Christ, thirsting for Christ, condemning anything earthly, he sighs for that vision of eternal clarity.]

This kind of language appears throughout Rolle's writings, but its concentration at this point in such a short work is unusual, especially since, rather than being directly tied to anything in the biblical text, it is simply describing the "lover" with

\footnotetext{
${ }^{57}$ Note that the scribe fits one more line of text within the bounding lines of fol. 166vb than he did in fol. 166va, and he then copied the last phrases of Super Quicunque vult below the lower bounding line of the second column.

${ }^{58}$ Watson, Invention of Authority, 103-4.

${ }^{59}$ Hanna, "Transmission," 328.

${ }^{60}$ Watson, Invention of Authority, 103.
}

Speculum 94/4 (October 2019) 
regard to whom the Hermit said the canticle could "not inappropriately" be interpreted. ${ }^{61}$ Instead of carefully explicating scripture-as he does, for example, in the Latin Psalter-Rolle appears to have used the Marian canticle as an occasion to repeat (perhaps derivatively) some of his favorite themes. Likewise, the commentary's abrupt ending suggests either its author's waning interest or his limited space. His gloss on the canticle's final verse reads, in full:

Sicut locutus est et cetera. Ad hunc enim finem locutus Spiritus sanctus prophetis et Apostolis vt cuntis vanitatibus despectis ad eternam gloriam pertingamus, ad quam nos perducat Iesus Christus. Amen. ${ }^{62}$

[As he spoke etc. To this end the Holy Ghost spoke to the prophets and apostles, so that having scorned all vanities we might arrive at eternal glory. May Jesus Christ lead us there. Amen.]

Rather than the work of "a young writer ... concerned to gain acceptance" and therefore "likely to begin his career with cautious imitation," the notion of this piece as filler prepared by a scribal author-unoriginal because largely spontaneous, meant to complete a specific volume-could allow for its composition at almost any point in the Hermit's career. ${ }^{63}$

For Super Quicunque vult, Watson's early dating depends entirely on the text's unoriginality. ${ }^{64}$ Even more than the other short commentaries, this work is wholly derivative, presenting a continuous prose transcription of interpretations drawn selectively from a copy of the Pseudo-Athanasian Creed with marginal glosses. ${ }^{65}$ Apart from the copy derived from it (discussed below), Bodley is one of only two

\footnotetext{
${ }^{61}$ Compare, for example, the exuberant ending to which the third lection of the Exposicio builds (Moyes, Introduction and Contribution, 2:186-87), concluding with a resumptive quotation of the lemma, Job 10.12b (in italics): "Et sic profecto dum spiritus a malicia auersus omni quoque bono conuersus eterno amore rapitur et sancte ac salubriter per diuinam uisitacionem custoditur, quamobrem electa anima Christum laudans et glorificans letanter prorumpat in canticum dicens: Ecce ad te uenio, quia uisitacio tua custodit spiritum meum."

${ }^{62}$ Bodley 861, fol. 166rb. This ending is consistent across the other copies, BodL, MS Ashmole 751, fol. 31v; BodL, MS Rawlinson C. 397, fol. 1vb; and Cambridge, Fitzwilliam Museum, MS 356, fol. 202r-205r. On Rawlinson C. 397, see William Macray, Catalogi codicum manuscriptorum Bibliothecae Bodleianae partis quintae fasciculus secundus, viri munificentissimi Ricardi Rawlinson, JCD, codicum classem tertiam (Oxford, 1878), 181-82; on Fitzwilliam 356, see Francis Wormald and Phyllis Giles, A Descriptive Catalogue of the Additional Illuminated Manuscripts in the Fitzwilliam Museum (Cambridge, UK, 1982), 1:351-53; and on Ashmole 751, see William Henry Black, Catalogue of the Manuscripts Bequeathed unto the University of Oxford by Elias Ashmole (Oxford, 1845), 362-65; Hanna, Pursuing History, 28-29; and Nicole Rice, Lay Piety and Religious Discipline in Middle English Literature, Cambridge Studies in Medieval Literature 73 (Cambridge, UK, 2008), 140-48. My thanks to Hannah Ryley for sending reproductions of the Oxford copies of this text.

${ }^{63}$ Watson, Invention of Authority, 96. Watson does not discuss the borrowings between Super Magnificat and the vernacular gloss on the canticle accompanying Rolle's English Psalter, observed by Allen, Writings Ascribed, 193. It could be that the literal Marian reading in the English Psalter predates and was the source for the tropological reading of Super Magnificat (which, as we have seen, Rolle regarded as something new)-in which case Super Magnificat could be quite late indeed.

${ }^{64}$ Watson, Invention of Authority, 96 and 277-78.

${ }^{65}$ G. D. W. Ommanney, A Critical Dissertation on the Athanasian Creed: Its Original Language, Date, Authorship, Titles, Text, Reception and Use (Oxford, 1897), 250-53, cited by Allen, Writings Ascribed, 312. Nikolaus Häring, "Commentaries on the Pseudo-Athanasian Creed," Mediaeval Studies 34 (1972): 208-52, summarizes Ommanney's work.
}

Speculum 94/4 (October 2019) 
manuscripts to preserve this prose abridgement, though its printing among Rolle's works in 1535 and 1536 indicates that it circulated in at least one other copy, where it was presented in a way that suggested its authenticity. ${ }^{66}$ Super Quicunque vult thus appears to be the kind of basic catechetical work that could easily be prepared on the fly-like Super Magnificat, though in this case by compilation or adaptation rather than impromptu composition-simply to fill out space remaining at the end of a quire. If Rolle did cobble it together after copying one of his other works to complete an autograph, this decision may reflect his understanding of the needs or preferences of a specific intended reader, and it would, again, be difficult to know when in his career this derivative commentary was prepared.

By reassessing the status of these short works in the Hermit's canon, it becomes easier to see how the Bodley scribe was able to identify them and include them in his growing anthology. That is, it seems likely that he found them together with other works he knew to be by Rolle, and he judged them to be authentic as well. Yet collocation is, on its own, an unsatisfying basis for such an attribution, since anything following a known Rollean text could just as easily be the work of another author, joined to the Hermit's work either fortuitously or to reflect the preferences of a scribe or his patron. ${ }^{67}$ Here it is important to recall the marginal annotations in which the Bodley scribe indicates his preference for old books, as well as his attempted reordering of Contra amatores and Incendium on the basis of a second (and apparently more authoritative) exemplar. As in these cases, his judgment about the authenticity of Rolle's conventional or less idiosyncratic commentaries seems likely to reflect this scribe's consideration of the authority of whole books rather than individual texts. He seems, in other words, first to have determined that an individual book is an authentically Rollean production, and this judgment then led him to accept the authenticity of the works that volume contains, even material in the seemingly unimportant and potentially anonymous position of filler. This general valuing of whole books could be an indication that the scribe was specifically attempting to locate Rolle's autographs, whether genuine or simply purported, though he never makes such a claim in his annotations, and his judgments could just as easily have been informed by what an owner had to say about a book's provenance-that, for example, a book had been copied from a genuine autograph rather than being one itself. ${ }^{68}$ Regardless, like the idea that one arrangement of the Hermit's major works could be more authoritative than another, the recognition

\footnotetext{
${ }^{66}$ D. Richardi Pampolitani eremitae, scriptoris perquam vetusti ac eruditi, de Emendatione peccatoris opusculum, nunc primum typis excusum, cum aliis aliquot appendicibus, quas versa indicabit pagella, ed. Johannes Faber (Cologne, 1535), sig. F2r-F7v; for the same text in the 1536 edition, cited above, see sig. e1r-e3r. The further manuscript copy, unknown to Allen, is Illinois 145, fols. 13r-18r, discussed in Kraebel, "Latin Manuscripts of Rolle." In both printings, as in Illinois 145, Super Quicunque vult follows after the paired Super Orationem and Super Symbolum, suggesting its collocation with those texts in Faber's copy text and the exemplar for Illinois 145 (which may have been the same book or booklet).

${ }^{67}$ Complicating this scenario is the increasing popularity of compilations of miscellaneous extracts from longer texts, in which contexts authorship might not always be noted. Several of Rolle's Latin works were, for example, excerpted in precisely this manner in the creation of a devotional compilation preserved in BodL, MS Hatton 97 and CUL, MS Ff.1.14. Rolle is named as an authority, but extracts from his writings are not consistently distinguished from those drawn from other sources.

${ }^{68}$ See, by way of contrast, the various owners who specifically claimed that their volumes of Rolle's works were written "in manu sua," listed above, n. 12.
}

Speculum 94/4 (October 2019) 
of Rolle as a writer of the kind of filler frequently found at the end of books implies that this careful compiler thought of his author as performing the work of a scribe, and he therefore valued not simply his texts but also what Rolle produced as a writer of books or booklets.

The Bodley scribe's recognition of Rolle as a scribal author would help to explain many of the details about the approach he took to making his volume-why he deferred decisions about how to arrange texts, and why he chose to include some works that would otherwise be hard to recognize as the Hermit's writings-but it also potentially troubles our understanding of the corpus he assembled. Before taking up the question of how his compilation was regarded, in turn, by another team of scribes, it is worth considering some of the more problematic implications not just of Rolle's potential work as a scribe, but of the Bodley scribe's apparent ability to exercise a degree of critical judgment concerning his author's scribal work. This scribe's judgment is now clearly valuable, insofar as it allowed him to preserve Rollean texts that would otherwise only survive, like Super Quicunque vult, in a single manuscript or in early modern printed editions, or, like Super Apocalypsim, in defective or severely damaged fragments. ${ }^{69}$ It becomes problematic, however, when he chooses to include - and therefore potentially affirms the authenticity of-writings that are now only associated with the Hermit by virtue of their presence in Bodley. Its value as a witness to Rolle's corpus is especially tenuous in Booklet IV, the messily inverted fascicle described above. Because Allen fails to recognize the complex processes by which this booklet was constructed, she mistakenly posits that the first two texts now appearing in it-the commentary on the Song of Songs and the short De mandatis-were left over from an early stage in the volume's compilation, before the scribe "made a late decision" to focus on reassembling the Hermit's writings, and she does not consider the possibility that these texts could be authentically Rollean as well. ${ }^{70}$ Yet, as we have seen, the Bodley scribe not only decided to include them, but, by reversing the booklet, he took pains to ensure that the commentary on the Song would appear before Rolle's similarly conventional gloss on Lamentations (Super Threnos), presumably to reflect the canonical ordering of the two biblical books. ${ }^{71}$ Though the Song commentary's prologue is attested in two other manuscripts (one earlier and clearly of northern English provenance), the commentary itself is now unique to Bodley, and, considering the importance of this biblical book in his later works, it seems entirely plausible that Rolle could have borrowed the existing prologue and then, as he did for the Psalms, Lamentations, and Apocalypse, prepared a more conventional scholastic commentary on this book as well. ${ }^{72}$ The same

\footnotetext{
${ }^{69}$ Note that both these texts are also preserved in the copy derived from Bodley, discussed below. But, of course, that further copy only exists by virtue of the Bodley scribe's activities.

${ }^{70}$ Allen, Writings Ascribed, 23 and 32. Hanna, Editing Medieval Texts, 145, calls it "an anonymous commentary on the Canticle" without further comment. Friedrich Stegmüller, Repertorium Biblicum Medii Aevi, 12 vols. (Madrid, 1940 [recte 1950]-80), no. 7307.1, identifies it as pseudonymous Rolle.

${ }^{71}$ That is, according to the ordering established in Paris Bibles: see Laura Light, "The Thirteenth Century and the Paris Bible," in The New Cambridge Historv of the Bible, vol. 2, From 600 to 1450, ed. Richard Marsden and E. Ann Matter (Cambridge, UK, 2012), 384.

${ }^{72}$ The commentary begins, "Osculetur . . . id est refeccione oris sui, id est Filii sui nos reficiat," while the prologue begins, "Materia huius operis sunt fideles." In Prague, Národní knihovna České republiky, MS XX.B.4, the prologue appears on fol. 108rv, but it is then followed by a widely copied commentary
}

Speculum 94/4 (October 2019) 
may be true of De mandatis, a redaction of a gloss on the Ten Commandments drawn from Isidore's Quaestiones in Veterum Testamentum and expanded (apparently uniquely) in Bodley by pairing each commandment with one of the ten plagues of Egypt. ${ }^{73}$ The awkward presentation of that text on fol. $137 \mathrm{v}$ (noted above) would appear to identify it as filler in Bodley, meant to take up space remaining after the conclusion of the Song commentary. Yet, again, by the time he copied De mandatis the scribe had already decided to invert Booklet IV, meaning that this "filler" was always going to appear at the middle (rather than the end) of the quire. Had he omitted it, he would have simply produced another instance of a text concluding on a verso with a new text beginning on the facing recto, as was apparently his design in Booklets V and, perhaps, III (see above). The copying of De mandatis therefore seems more motivated, and it could be, again, that he included it because he found it in a volume deemed to have a certain degree of authority. ${ }^{74}$ Given this scribe's ability to locate and identify otherwise poorly attested authentic works (Super Threnos, Super Apocalypsim, Super Magnificat, Super Quicunque vult), he could have succeeded in preserving genuine examples of the Hermit's writings in these cases as well.

In addition to accounting for his particular interest in locating old books, the Bodley scribe's apparent aspiration to judge his exemplars as potentially reflecting the work of a scribal author offers suggestive evidence of the codicological settings in which he found the works he copied. To take this evidence seriously, we need not accept the authenticity of every work he includes-indeed, the position of these works in the Rollean canon, whether as fairly conventional compositions, derivative compilations, or adaptive scribal stints, will likely always be provisional and speculative. Yet our understanding of the Hermit will remain incomplete until these works are taken into account. Just as it is important to continue pursuing the implications of Fisher's claim that "nearly all authors" in the later Middle Ages "were scribes," so too must we develop a critical appreciation of what it would mean for medieval scribes to be aware of this facet of literary production..$^{75}$ Though it might not always shape how

perhaps by Haimo of Auxerre (fols. 108v-135r): Stegmüller, Repertorium, no. 1895/3079. On the copying of English-provenance texts in Bohemia, see Michael Van Dussen, From England to Bohemia: Heresy and Communication in the Later Middle Ages, Cambridge Studies in Medieval Literature 86 (Cambridge, UK, 2012), esp. 37-62. The Hague, Koninklijke Bibliothek, MS 73 E 20, includes other Yorkshire texts, e.g., the sermons of William of Newburgh (fols. $14 \mathrm{v}-24 \mathrm{v}$ ). This manuscript is copied in an early thirteenth-century English bookhand, but it contains only a fragment of the prologue (fol. 46v) before breaking off, and it is unclear whether a full commentary followed (and, if so, which commentary); cf. Stegmüller, Repertorium, no. 9313. On the importance of the Song in Rolle's writings, see Renevey, Language, Self, and Love.

${ }^{73}$ Hanna, Editing Medieval Texts, 145, identifies this text with a marginal comment in the Glossa ordinaria on Exod. 20.2, citing PL 113:250b-c; this bit of the Glossa is related to the material in Bodley, but only because it shares Isidore as a source. For the Quaestiones, see PL 83:301a-303c. The Isidore text was apparently extracted and circulated as a separate piece of pastoralia, seen, e.g., in BnF, MS lat. 13372, fol. 89v, a manuscript from Saint-Germain-des-Prés that was almost certainly the source for Luc d'Achery's edition, underlying PL 100:567c-570d. The version in Bodley expands on that text.

${ }^{74}$ As noted above, the date in the explicit to the Song commentary indicates that it was one of the last things the scribe copied, and since, as discussed below, he was sending booklets back home throughout his campaign, it could be that he was running out of suitable places in which to copy De mandatis.

${ }^{75}$ Fisher, Scribal Authorship, 6.

Speculum 94/4 (October 2019) 
they copied texts, nearly all medieval scribes must, on some level, have been aware that those texts could have originated in an act of scribal authorship.

\section{Notes From the NorTH}

If his manuscript now provided the only evidence for the Bodley scribe's workthat is, if the processes by which his anthology was created could be recovered only from its state as a final product - then his book might simply appear to be the idiosyncratic compilation of a diligent scribe devoted to Rolle's brand of piety. ${ }^{76}$ Fortunately, a second volume, now Hereford, Cathedral Library, MS O.VIII.1, can be identified not only as copied from Bodley, but as a planned fair copy produced under the guidance of the Bodley scribe and using materials dispatched from his travels. Noting that the team of scribes responsible for producing Hereford was in contact with the scribe of Bodley helps to localize the production of both manuscripts, potentially indicating, if not the identity of the Bodley scribe, then the community of readers to which he belonged. Further, considered alongside Hereford, Bodley's comparative messiness becomes more fully explicable, reflecting, at least in part, its status as a "working copy" intended to facilitate the production of this more polished book. ${ }^{77}$ In other words, the Bodley scribe not only worked to locate, copy, and compare as fully as he could the corpus of the Hermit's Latin, but he also had to present his findings so that they were intelligible to a further group of copyists.

Hereford O.VIII.1 is a parchment volume bearing eight of the Hermit's Latin writings, all of which also appear in Bodley. ${ }^{78}$ The possibility that there is "a certain connexion" between these two manuscripts is now a century old, first raised by Margaret Deanesly and then repeated by other early editors, with Allen suggesting that the makers of the two books "perhaps used the same original or a derivative."79

\footnotetext{
${ }^{76}$ This is essentially the conclusion of Jonathan Hughes, Pastors and Visionaries: Religion and Secular Life in Late Medieval Yorkshire (Woodbridge, UK, 1988), 107-8, who claims that the Bodley scribe "was probably a north-country hermit."

${ }^{77}$ The term "working copy" is typically applied to authorial autographs, and discussions of them tend to focus not on the construction of manuscripts but on what Richard Beadle, "English Autograph Writings of the Later Middle Ages: Some Preliminaries," in Gli autografi medievali: Problemi paleografici e filologici; Atti del Convegno di studio della Fondazione Ezio Franceschini, Erice, 25 settembre-2 ottobre 1990, ed. Paolo Chiesa and Lucia Pinelli (Spoleto, 1994), 249-68, at 258, calls the "untidy and contingent processes" of composing and revising texts. Certainly, the scribe of Bodley shares some of the priorities with the scribal authors of such volumes, insofar as he is willing to revise the texts he has copied (though, in his case, in light of readings found in further witnesses). See further Wakelin, Scribal Correction, 279-81; and Matthew Fisher, "When Variants Aren't: Authors as Scribes in Some English Manuscripts," in Probable Truth: Editing Medieval Texts from Britain in the Twenty-First Century, ed. Vincent Gillespie and Anne Hudson, Texts and Transitions 5 (Turnhout, 2013), 207-22, esp. 216-22.

${ }^{78}$ Eight, that is, if the Super Quicunque vult is accepted as "written" by Rolle in one of the senses discussed above. For a description, see R. A. B. Mynors and Rodney Thomson, Catalogue of the Manuscripts of Hereford Cathedral Library (Cambridge, UK, 1993), 53.

${ }^{79}$ Incendium, ed. Deanesly, 18, who does not make any further suggestions about the relations among the different manuscripts; cf. Hanna, "Rolle's Incendium." Allen, Writings Ascribed, 26 and 312, quoted in Melos, ed. Arnould, lxxiii, and cited in Contra amatores mundi, ed. Paul Theiner (Berkeley, 1968), 46 n. 21. In his remarks on the history of the text, after noting that Bodley 861 and Hereford O.VIII.1 "fairly frequently agree," Theiner (58-59) focuses on the errors that Hereford shares with another copy, BodL, MS Bodley 769-but this copy is later and most likely derives from Hereford O.VIII.1.
}

Speculum 94/4 (October 2019) 
It was Marzac who realized that, for Super Apocalypsim, Bodley served as Hereford's exemplar, and she argues that many of Hereford's unique variants "can be explained by the material disposition of the text" in Bodley. ${ }^{80}$ Marzac's insights and her paired focus on textual and material evidence were extended by Roger Mynors and Rodney Thomson in the course of explaining Hereford's unusual presentation of Incendium and Super Canticum. As they note, Incendium is incomplete, ending mid-sentence on fol. 106v, at which point Super Canticum begins, also mid-sentence and without any indication of a change in text. The scribe responsible for this stint in Hereford apparently believed that he was still copying Incendium, not noticing "that he had run two of Rolle's works together." ${ }^{81}$ His mistake can be explained if the scribe had been copying from the unbound and misordered quires of Bodley's Booklet II (see Fig. 1): the last words of Incendium in Hereford correspond to the end of Bodley's Quire 9 (fol. 110vb), while the first words of Hereford's Super Canticum match the beginning of Bodley's Quire 8 (fol. 87va). ${ }^{82}$

But the scribes of Hereford did not have straightforward or simultaneous access to the loose quires now bound together in Bodley, and they could not simply select from its offerings to copy their new volume in a single planned production unit. As Fig. 2 indicates, Hereford's eight texts are instead divided over four fascicles, with breaks made clear by inconsistencies in the size of quires (generally in twelves, but Booklet II in fourteen) and by various blank leaves (fols. 82 and 83 , fol. 144v). ${ }^{83}$ This structure may, in part, result from an attempt to divide the labor of writing the book among different scribes: Booklet IV is copied in one hand, and Booklet III is begun in another (Quires 9 and 10) and completed by at least two more (fols. 122r-137v + 138r-144r). ${ }^{84}$ Another hand is clearly responsible for both Booklets I and II, however, and the distribution of a single scribe's work over two fascicles suggests that something else may have been motivating this piecemeal approach to the manuscript's production. ${ }^{85}$ This likelihood is strengthened by correspondences between

\footnotetext{
${ }^{80}$ Super Apocalypsim, ed. Marzac, 82: "Bien des fautes de B [Hereford O.VIII.1] s'expliquent par la disposition matérielle du texte dans le manuscrit A [Bodley 861]: modèle de B n'est donc pas un manuscrit hypothétique, mais A lui-même.”

${ }^{81}$ Mynors and Thomson, Catalogue of the Manuscripts of Hereford, 53. Deanesly had earlier noted the running together of the texts (Incendium, 33). Cf. Hanna, Editing Medieval Texts, 147-48.

${ }^{82}$ Mynors and Thomson, Catalogue of the Manuscripts of Hereford, 53, mistakenly say "quire 8" for "quire 9" and "quire 7" for "quire 8"; Hanna, Editing Medieval Texts, 147-48, mistakenly says "quire 7" for "quire 8," but he confirms that Bodley was the exemplar for Incendium and Super Canticum in Hereford O.VIII.1. From my own work, I can add that the text of the Latin Psalter in Hereford O.VIII.1 is taken from Bodley 861: see Kraebel, Biblical Commentary and Translation in Later Medieval England: Experiments in Interpretation, Cambridge Studies in Medieval Literature 109 (Cambridge, UK, forthcoming), Appendix B.

${ }^{83}$ Robinson, "Booklet," 48 (nos. 7 and 9).

${ }^{84}$ I say "at least" because, as Mynors and Thomson note (53), the hand responsible for copying fols. $122 \mathrm{r}-137 \mathrm{v}$ breaks off before completing the second column of the final verso, and the missing material is supplied in apparently two further, distinct hands.

${ }^{85}$ The phenomenon of booklets arising from the division of a large job among different scribes is associated particularly with coordinated metropolitan book production: see M. B. Parkes and A. I. Doyle, "The Production of Copies of the Canterbury Tales and Confessio Amantis in the Early Fifteenth Century," in Parkes, Scribes, Scripts, and Readers: Studies in the Communication, Presentation, and Dissemination of Medieval Texts (London, 2003), 201-48. See also Kwakkel's “type 1" single-author collections: "Late Medieval Text Collections," 62-64.
}

Speculum 94/4 (October 2019) 


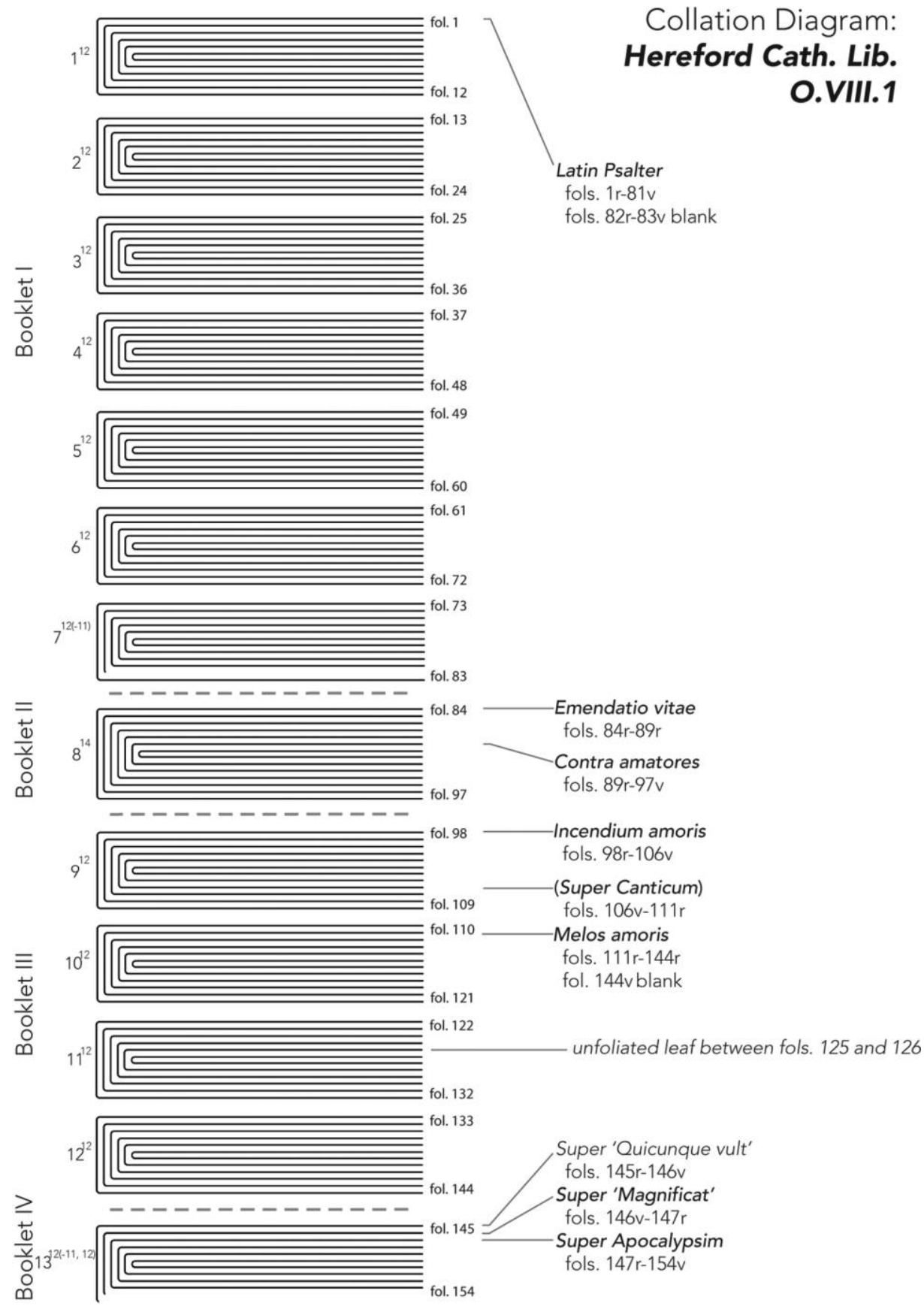

Fig. 2. The booklet and quire structure of Hereford, Cathedral Library, MS O.VIII.1. For conventions, see Fig. 1. 
the different booklets in Bodley and Hereford, with (most obviously) the same text copied in Booklet I in both manuscripts, while Hereford's Booklet IV brings together all the complete texts in Bodley's Booklets III and VI, and all but one of the texts in Hereford's Booklets II and III appear in Bodley's early and large Booklet II. These groupings of texts and divisions of stints point to the Hereford scribes receiving Bodley's booklets in batches and therefore copying in fascicles (to recall Gillespie's useful phrase) "to accommodate the arrival of new material, and to anticipate the failure of that material to arrive." 86

This specific connection between the two manuscripts—with Bodley providing, in intermittently received pieces, an exemplar for Hereford-helps to explain another highly unusual, perhaps unique, form of annotation in Bodley, providing evidence that this scribe was not only aware that his booklets were being used to produce another volume, but also that he was working, from afar, to oversee that volume's construction. Two thin tags or strips of paper are now sewn onto fols. 103 and 143 of Bodley, each containing notes in the Bodley scribe's hand (see Fig. 3 for the positioning of the tags, and Figs. 4 and 5 for details). Both strips have been folded in half around the outer edge of the folio close to the top of the leaf, such that the top of the strip is roughly parallel to the folio's upper edge and the text on the tag appears in the same direction as the text on the rest of the page. Stitching through both halves of the strips makes it impossible to unfold them or to read them without turning the folio. In both cases the ink is faded, and some of the text has been worn away over the fold. Further, though the notes appear to describe the arrangement of Bodley's quires, their meaning is somewhat obscured by the knowledge the scribe assumes on the part of his reader. With these caveats, it is at least clear that the first tag, appearing toward the beginning of Incendium, refers to a problem arranging the sheets and quires of what is now Bodley's Booklet II: ${ }^{87}$

Hic incipit liber iii qui vocatur Incendium amoris. Habet xxii c[[apitula]]: "Admirabar amplius quam enuncio quando siquidem sentiui cor meum primitus.” Et hic caret folio in fine istius quaterni, et in princip[[io]] similiter istius quaterni caret folio. Et illud foli[um] non est secundum folium in quaterno quem clausum misi ad vos, quia est finis libri, et s[[ic]] habetis totum secundum librum De amore Dei contra amatores mundi in quaterno vestro clauso et signato. Verte folium caudam cum cap[[i]]te et ponatur in loco suo. Quia quilibet quaternus habet xii folia vester quaternus xvi.

[Here begins Book 3, which is called the Fire of Love. It has twenty-two chapters. "I cannot express how greatly I wondered when I first felt my heart." And here a folio is lacking at the end of that quire, and similarly at the beginning of that quire a folio is lacking. And that folio is not the second folio in the quire that I sent you sealed, for it is the end of the book, and thus you have the whole second book On the Love of God against the Lovers of the World in your sealed and signed quire. Reverse [? or fold] the folio tail to head and put it in its proper place. For whichever quire has twelve folios, your quire [? has] sixteen.]

${ }^{86}$ Gillespie, "Booklet Theory," 9. In light of the possible delays between stints in Hereford O.VIII.1, it could be that some of what Mynors and Thomson describe as the "neat Anglicana hands" responsible for the different stints identified above could be the work of a single scribe.

${ }^{87}$ Rubricated words are indicated with boldface here, and hypothetical reconstructions of material lost over the fold in this and the next example are put in double square brackets. One emendation is offered in single square brackets: "foli[um]" where the scribe has written "folio." Cp. Incendium, ed. Deanesly, 18-19 nn., and Allen, Writings Ascribed, 31 and 33.

Speculum 94/4 (October 2019) 


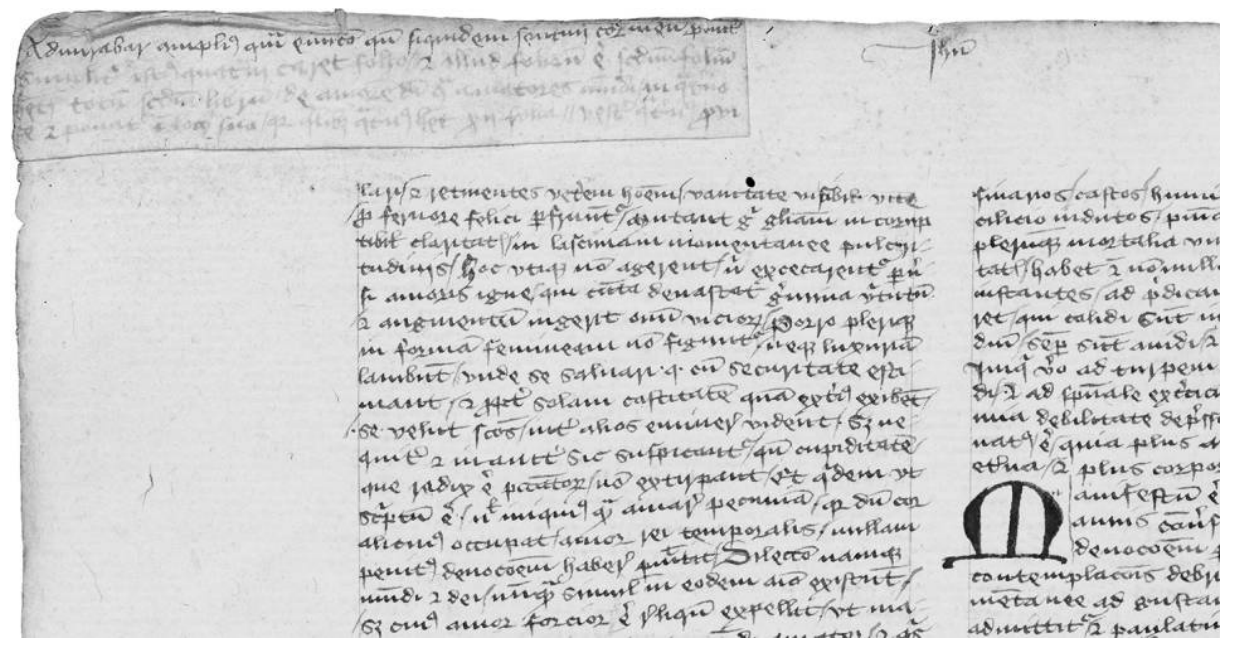

Fig. 3. The right half of the tag reproduced in detail in Fig. 4, showing its positioning on the leaf (here Bodley 861, fol. 103v). The scribe copies the monogram of the Holy Name in the upper margin of almost every page in the book. See the online edition for a color version of this image.

The scribe's addressee is apparently in possession of at least some of the material he copied ("in quaterno quem ... misi ad vos"), and there are some clear connections between what he has written here and annotations he added elsewhere in Bodley. The wrongheaded specification that Incendium has twenty-two chapters echoes the belated incipit squeezed between the lines on fol. 102rb and repeated after the text on fol. 122v, while the titling of Incendium, calling it a third book, repeats the marginal "liber 3" on fol. 102r in a form more closely resembling the incipit supplied for Contra amatores on fol. 93rb (see above). The portion of the note in text ink seems to address a separate issue, apparently indicating that the recipient of the scribe's note has confused the placement of the outermost bifolium of what is now Bodley's Quire 9 (on the first verso of which Contra amatores concludes; see Fig. 1). His command, "verte caudum cum capite," seems to indicate that the addressee had folded this bifolium incorrectly (perhaps having received it as an unfolded sheet) and, compounding the mistake, had thought it should be positioned second in the quire. When it is restored to its proper place, the recipient will "have the whole second book," Contra amatores, making it clear that he was in possession of what is now Quire 8 as well.

Following Deanesly, Allen believed that this note (along with the other, discussed below) was meant to direct the work of a contemporary binder, helping to ensure that the sheets of this large and messy volume were assembled in the proper order. ${ }^{88}$

\footnotetext{
${ }^{88}$ Allen, Writings Ascribed, 22, 31, and 32, citing Incendium, ed. Deanesly, 18-19. Both call the tags "bookbinder's notes." Perhaps because of this misinterpretation, Allen assumes that the scribe was responsible for affixing these notes to Bodley in their current position. In Writings Ascribed, 22, she associates the tags with a series of signatures which, as Hanna, Editing Medieval Texts, 142, notes, are "clearly a later addition." Hanna, "Transmission," 327, and Editing Medieval Texts, 147, recognizes that the tags are not bookbinder's notes but rather meant to help someone receiving batches of the Bodley scribe's sheets make sense of this material; he suggests that this is the scribe's "patron" or "director," not noting their potential role in guiding the production of Hereford O.VIII.1.
}

Speculum 94/4 (October 2019) 

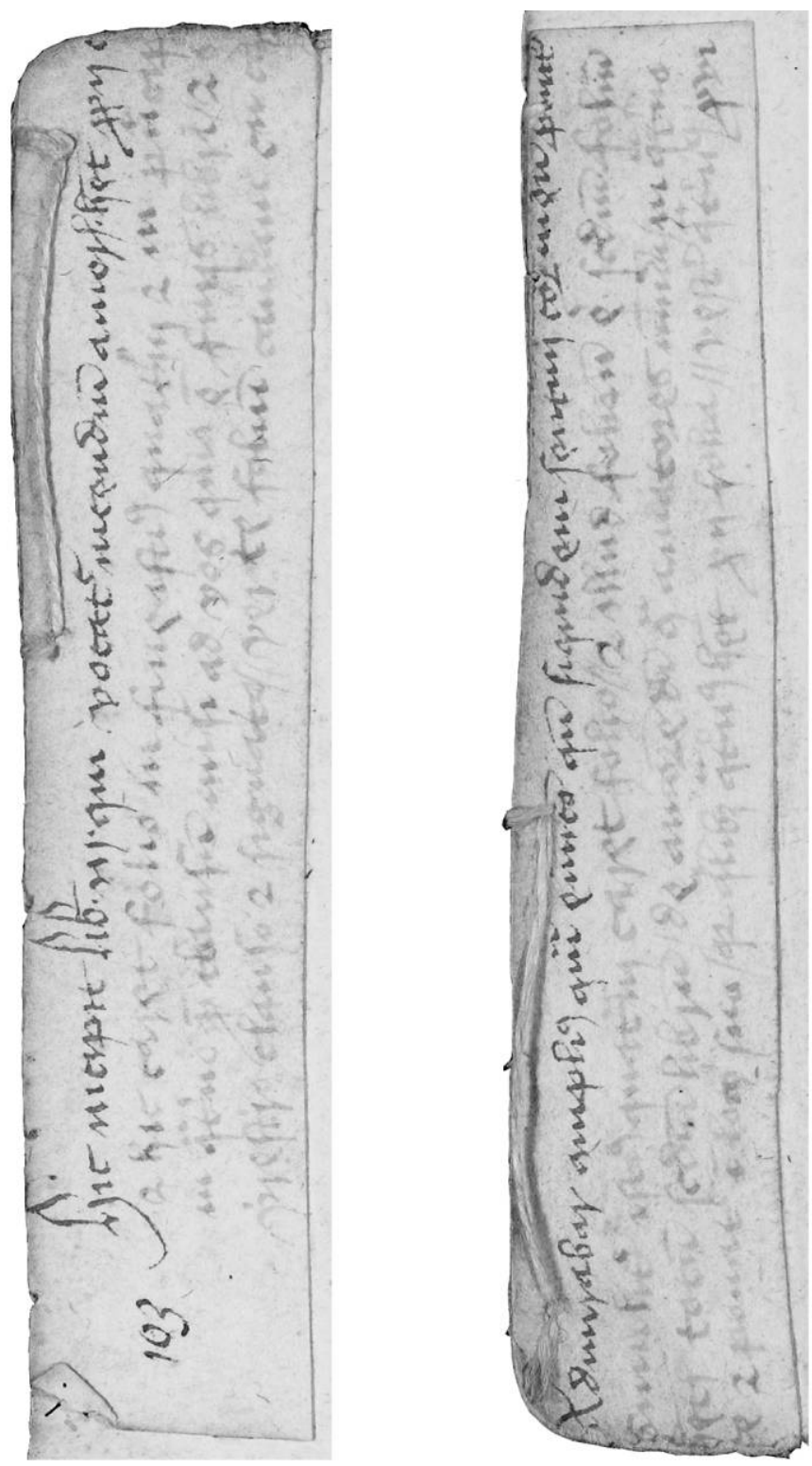

Fig. 4. The first of two tags now attached to Bodley 861 , this one wrapping around the outer edge at the top of fol. 103. The portion in the left image, with the first half of each line of text, appears on the recto, and the portion in the right image appears on the verso. See the online edition for a color version of these images.

But more of the note's details can be explained if it was instead addressed to another scribe, someone working at the Bodley scribe's direction in the task of preparing a more formal copy of the materials he supplied. According to this reading, the addressee needs to locate the end of Contra amatores because he is attempting to copy

Speculum 94/4 (October 2019) 

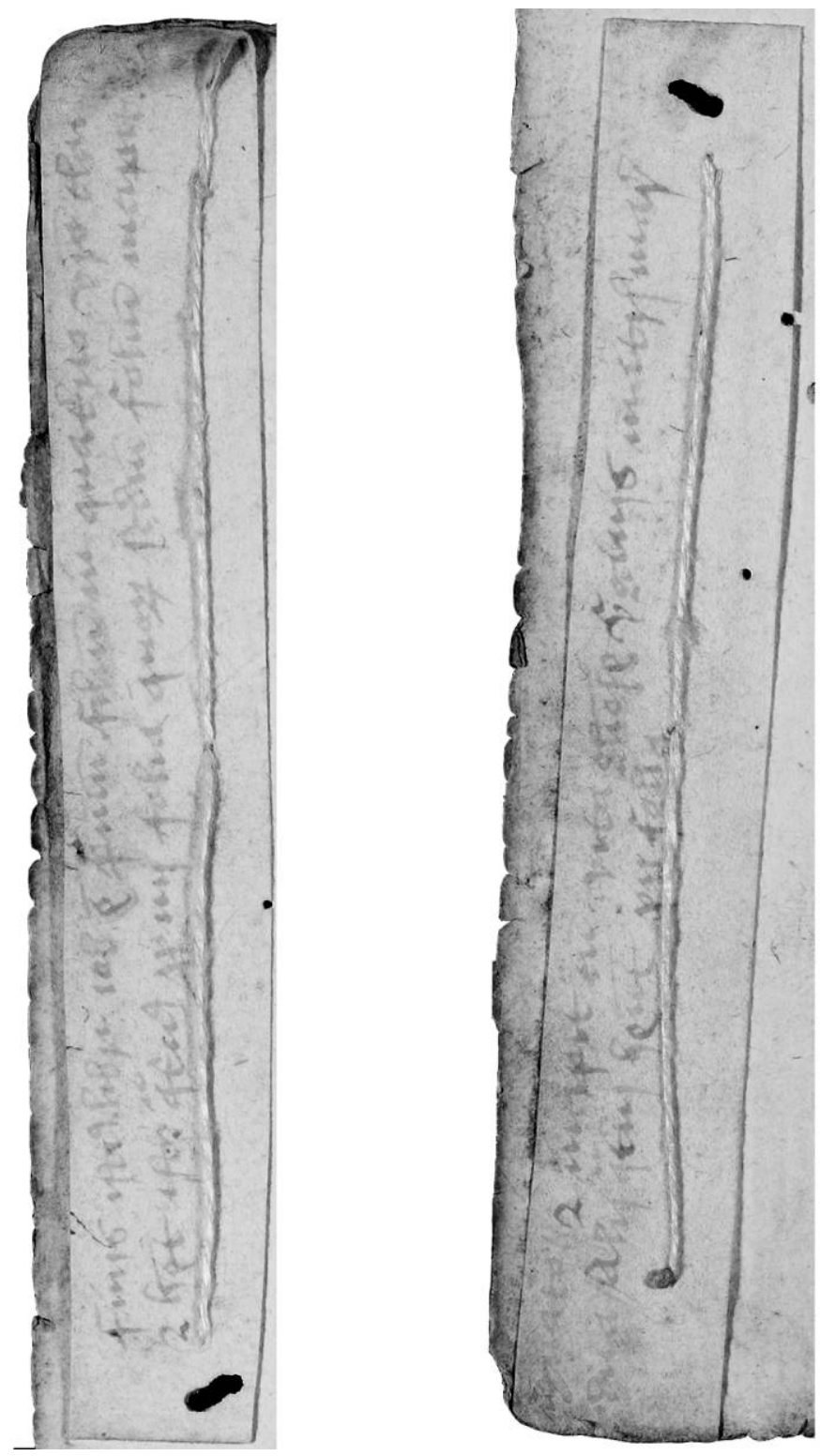

Fig. 5. The second tag in Bodley 861, wrapped around the outer edge at the top of fol. 143. Again, the half of the tag in the left image appears on the recto and the half in the right image appears on the verso. See the online edition for a color version of these images.

it. The Bodley scribe's awareness that a second copy of Rolle's works was being prepared from his booklets could explain the presence of the rubricated Incendium incipit in this note: after copying a fragmented and compressed version of it on fol. $102 \mathrm{vb}$, he is now indicating how it should be written, in its full form, in a subsequent copy of the Hermit's text. Further, if the Bodley scribe was indeed passing Speculum 94/4 (October 2019) 
his work along to another scribal team, then this note could suggest that his materials were being sent as individual quires (quaterni) or groups of quires, rather than completed booklets (libelli or fasciculi, neither of which he uses). In that case, it is likely that this note was first written along the outer edge of a sheet in a quire about to be dispatched, reaching its recipient in that form before being trimmed and, eventually, sewn at its present location. ${ }^{89}$ Finally, though more speculatively, this scenario could also account for the note's otherwise "unintelligible" final sentence, which Allen took to refer to a numbered quire: "Whatever quire has twelve folios [supply: is] your quire sixteen." Allen admits that her interpretation is problematic, since Bodley is made up of only fourteen quires, but there are more significant obstacles to this reading, especially that his use of "quilibet" seems to acknowledge that multiple quires will meet this description-as, indeed, will any quire now in Booklet II. ${ }^{90}$ This sentence therefore cannot plausibly be an attempt to identify a specific quire, but it could offer guidelines for the preparation of a second manuscript, indicating that the material in Bodley should be copied, presumably on a smaller page or in a larger script (or both), at a ratio of $12: 16 .^{91}$

If the rubricated incipit to Incendium was meant to guide that text's titling in Hereford, then the tag either arrived too late or its recipients only imperfectly understood the Bodley scribe's intention. Incendium begins in Hereford at the top of fol. 98ra without any space left for a title, and a correcting hand has added one in the upper margin, "Hic incipit tercius liber tercius." 92 Elsewhere in Hereford it seems that this corrector, still relatively inept, may have been working with materials supplied in similar notes that no longer survive. On fol. 111ra, the scribe has begun Melos leaving only one blank line after completing Super Canticum (which he presumably thought to be the conclusion of Incendium), and the corrector has added "Incipit liber quartus" at the top of the page, as well as a more detailed note in the inner margin: "Hic incipit quartus liber, De melis angelis, et faciatis bonum spacium" ("Here begins the fourth book, On Angel Songs, and leave a good space"; see Fig. 6). ${ }^{93}$ In this case, it is

\footnotetext{
${ }^{89}$ My thanks to Margaret Connolly for suggesting that these tags could have been written along an edge and trimmed. The current position of this tag may reflect a desire to display its fuller incipit of Incendium near the start of that text, which it now faces across an opening. The possibility that it is only preserved as a slip because it has been trimmed and sewn to Bodley would set it apart from other kinds of slips (schedulae) used for note taking or correction and interleaved in existing quires, on which see Erik Kwakkel, "Discarded Parchment as Writing Support in English Manuscript Culture," English Manuscript Studies 1100-1700 17 (2012): 243-46; Charles Burnett, "Give Him the White Cow: Notes and Note-Taking in the Universities in the Twelfth and Thirteenth Centuries," History of Universities 14 (1995-96): 16-20.

${ }^{90}$ Allen, Writings Ascribed, 31.

${ }^{91}$ For another manuscript copied at a planned proportion from a surviving exemplar, see N. R. Ker, Books, Collectors, and Libraries: Studies in the Medieval Heritage, History Series (Hambledon Press) 36 (London, 1985), 87-99.

${ }^{92}$ This correcting hand may be the same as the one that has made interlinear and marginal emendations throughout Hereford O.VIII.1, starting on fol. 1ra, sometimes erasing red penwork decoration (e.g., on fol. 111rb) to add omitted words. Mynors and Thomson, Catalogue of the Manuscripts of Hereford, 53, describe the titling done by "a small early hand" at the start of Incendium and Melos, but they do not mention other corrections.

${ }^{93}$ The note in the upper margin is written in a larger and slightly more formal script, but it is similar enough to be the work of the same corrector.
}

Speculum 94/4 (October 2019) 


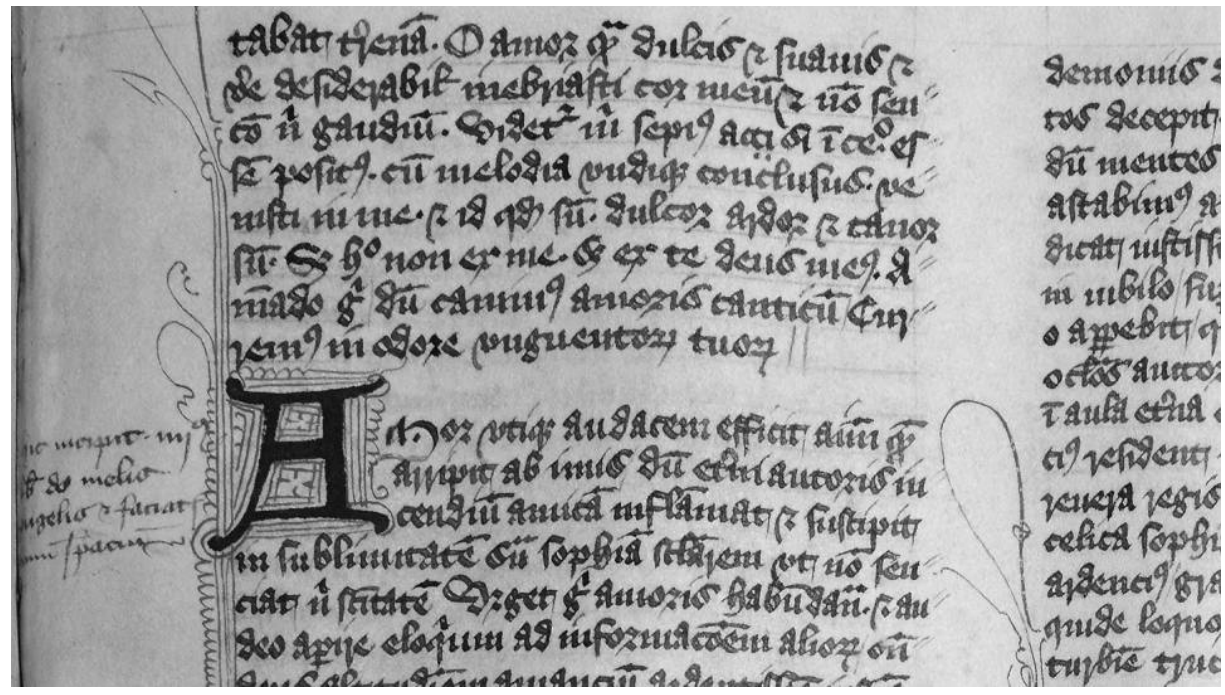

Fig. 6. The beginning of Melos in Hereford O.VIII.1, fol. 111ra, with a marginal note that may preserve material from the Bodley scribe's written instructions. See the online edition for a color version of this image.

possible that a note from the Bodley scribe (who begins Melos without any title on fol. 51r) has been confused, and the Hereford corrector has run together the intended title with an instruction for copying the text. ${ }^{94}$ Despite these blunders, the Hereford team clearly understood at least some of the information the Bodley scribe sought to convey, allowing them to reproduce the arrangement of texts, discussed above, that he found after he finished copying his Booklet II. In addition to these marginalia, the rubricated incipit to Contra amatores, which the Bodley scribe added before that text, identifying it as the second book in this sequence, is copied precisely at the start of that text in Hereford, fol. 89r. By implication, Emendatio, though simply titled Regula uiuendi on fol. $84 \mathrm{r}$, must begin the sequence as the liber primus. This orderingwith, again, Super Canticum only unintentionally included in Hereford-is confirmed by Oxford, Corpus Christi College, MS 193 (hereafter Corpus 193), where Emendatio, Contra amatores, Incendium, and Melos appear in the same order, though without titles making reference to the four-book sequence. ${ }^{95}$ (Either the Bodley scribe shared his discovery of this arrangement with the scribe of Corpus 193, or the book in which

${ }^{94}$ The title Melum contemplatiuorum is added at the top of Bodley 861, fol. $51 \mathrm{r}$, in a later hand, which has supplied other titles in Booklet II. A related title (Melum contemplatiuorum ardencium in amore Dei) occurs in the explicit to Corpus 193, fol. 51v, and in the incipit to Uppsala, Universitetsbiblioteket, MS C.1, fol. 34r. The title Melos contemplativorum occurs in Cambridge, Saint John's College, MS 23, fol. 41r, to which Arnould believed Uppsala was related (Melos, lxxi). Based on his bungling of the title of Incendium, it could be that the Hereford corrector's Angelis (otherwise unattested) was a mistake for the more common Amoris.

${ }^{95}$ Corpus 193, fols. 165r-251v. See Thomson, Manuscripts of Corpus Christi College, 97. Numbering these texts (rather than just presenting them in sequence) may have been the Bodley scribe's innovation, adopted to help convey the desired arrangement to the Hereford team.

Speculum 94/4 (October 2019) 
the Bodley scribe found it served as Corpus 193's exemplar. ${ }^{96}$ Regardless of the titling errors, then, at least this larger organizational scheme was conveyed successfully to the Hereford team, and it too may have been set out in notes accompanying the sheets that now make up Bodley.

In a loose sense, the kind of information conveyed by the note on fol. 103 is communicated commonly in fascicular manuscripts, where scribes and owners often worked to ensure that their growing collections would be bound in a specific order. In most cases, the desired arrangement is indicated by quire signatures, which could be revised as needed to accommodate new material..$^{97}$ In the note quoted above, the Bodley scribe does refer to a quire as "clausus et signatus," but this pairing is used idiomatically to describe the treatment of correspondence, and it is therefore more likely that, in this context, "signatus" means "sealed" rather than "signed" in the bibliographical sense..$^{98}$ Likewise, though a series of signatures appears throughout Bodley, restarting in each booklet, these are not in the same hand as the text, and they may have been added as the scribe's correspondents assembled his quires in the proper order. ${ }^{99}$ In any event, this approach would only be useful for as long as the Bodley scribe had access to his sheets and could revise signatures to describe a new arrangement: as soon as his quires were dispatched to the Hereford team he could only (at best) add signatures to newly copied materials to indicate their position relative to the units he no longer possessed. Instead, his notes seem more closely to resemble the instructions to illuminators that accompanied some late medieval texts, surviving because they were sometimes copied as captions for the images they

\footnotetext{
${ }^{96}$ Hanna, "Transmission," 330, is slightly misleading when he claims that "the individual responsible for Corpus ... a almost certainly knew the Hereford scribe's solution" to the ordering of these texts and, certainly, his suggestion that Hereford was "probably the direct source of Corpus" cannot be right (Hanna, "Making Miscellaneous Manuscripts," 2). As noted above, Corpus 193 was in Yorkshire until the Dissolution, and below we will see that Hereford's production can be localized to the West Midlands: the Bodley scribe's intermediating activities, communicating information from a manuscript also accessible to the makers of Corpus 193, must account for the similarities in the two books. Hanna, "Transmission," 329, also gives a confused account of how the four-book arrangement is reflected in Bodley 861. Apart from its appearance before Contra amatores, there is no reason to think (as he suggests) that the Bodley scribe considered Super Canticum to be the first book in this sequence, and Emendatio is not "mark[ed]" as the fourth book.

${ }^{97}$ Hanna is, of course, the master of describing these complicated rearrangements: see "Producing Magdalen College MS lat. 93," Yearbook of English Studies 33 (2003): 142-55; "Merton College MS 68: Production and Texts," Bodleian Library Record 27 (2014): 129-52; “'Classicising Friars,' Miscellaneous Transmission, and MS Royal 7 C. I," Journal of the Early Book Society 19 (2016): 97-124. My work editing the Exposicio has identified BodL, MS Bodley 52 as another pertinent example: its five booklets are signed (1) o-s, (2) k-n, (3) [single unsigned quire], (4) t, (5) $\pi-\mathrm{j}$.

${ }^{98}$ Allen, Writings Ascribed, 31, takes the word in a bibliographical sense. Perhaps deriving from "clusit et signavit" in Apoc. 20.3 and the "hortus conclusus, fons signatus" of Song of Songs 4.12, the phrase "clausus et signatus" commonly refers to something that has been closed and sealed (with wax), in this case describing the packaging of the loose quires. For relevant definitions, see The Dictionary of Medieval Latin from British Sources (hereafter DMLBS, available at http://logeion.uchi cago.edu), s.vv. "claudere" 3b and "signare" 5; for examples, see PL 120:1377c, 167:1637b, 168:875b, $169: 110 \mathrm{bc}$ and $925 \mathrm{~d}, 188: 337 \mathrm{~d}$, and 190:1336c.

${ }^{99}$ These signatures are detailed by Hanna, Editing Medieval Texts, 142-46. Scribal signatures could, of course, have been trimmed away-and in some places in Booklet I, where two sets of signatures are visible, the ones along the lowermost edge may plausibly be scribal (e.g., fol. 39r).
}

Speculum 94/4 (October 2019) 
describe. ${ }^{100}$ Both the notes to illustrators and the notes in Bodley seek to convey complex information about the presentation of texts copied in subsequent volumes, whether focusing on illustration, the ordering and titling of writings, or the proper arrangement of stray leaves. ${ }^{101}$ Likewise, in both cases the notes' writers are presumed to be absent when these new copies are prepared-accounting, perhaps, for their sometimes pedantic level of detail, and for misunderstandings and blunders in the manuscripts produced on the basis of such instructions. ${ }^{102}$ The apparently unique survival of the Bodley notes as attached tags also raises the possibility, like the inconsistent copying of instructions to illuminators, that more such notes once existed, similarly trimmed away but not preserved. That is, they could have been a more common feature of manuscript production than the current state of medieval books now suggests. ${ }^{103}$

The second tag, sewn along the upper edge of fol. 143, apparently confirms the possibility that the signatures now visible in Bodley were added by the recipient of the scribe's materials (Fig. 5). Compared to the one on fol. 103, the content of this note is straightforward, but it still fills in details of the production of at least Bodley, if not also Hereford. Written entirely in text ink, it reads:

Finis istius libri Iob est primum folium in quaterno vestro cla[[uso et s]]ignato, et incipit cum vita gloriose Virginis Matris Marie, et habet iste quaternus xxiiii folia quorum secundum folium incipit c[[um Oracione]] Dominica. Alii quaterni habent xii folia.

[The end of that book of Job is the first folio [? bifolium] in your closed and sealed quire, and it begins with the Life of the glorious Virgin Mother Mary, and that quire has twentyfour folios, the second beginning with the Lord's Prayer. Other quires have twelve folios.]

${ }^{100}$ Martha Driver and Michael Orr, "Decorating and Illustrating the Page," in Production of Books, ed. Gillespie and Wakelin, 120-22; Jonathan Alexander, Medieval Illuminators and Their Methods of Work (New Haven, 1992), 52-71. For specific examples, see Richard and Mary Rouse, Manuscripts and Their Makers: Commercial Book Producers in Medieval Paris, 1200-1500, 2 vols., Studies in Medieval and Early Renaissance Art History 25 (Turnhout, 2000), 1:145-71 and 2:170-72; Anne Hedeman, "Making the Past Present: Visual Translation in Jean Lebègue's 'Twin' Manuscripts of Sallust," in Patrons, Authors, and Workshops: Books and Book Production in Paris around 1400, ed. Godfried Croenen and Peter Ainsworth, Synthema 4 (Louvain, 2006), 173-96. English examples appear to be rare, but see Lucy Freeman Sandler, "Notes for the Illuminator: The Case of the Omne bonum," Art Bulletin 71 (1989): 551-64. Kathleen Scott, Later Gothic Manuscripts, 1390-1490, 2 vols. (London, 1996), 2:193, suggests that such instructions (poorly understood by the illuminator) could explain the images in the Desert of Religion as copied in BL, MS Stowe 39. Jessica Brantley, Reading in the Wilderness: Private Devotion and Public Performance in Late Medieval England (Chicago, 2007), 358 n. 46, suggests the further possibility that these misunderstood instructions could explain the disposition of the text and images in Stowe 39: while the two other copies of the Desert present the text and image in parallel columns, Stowe 39 divides its pages into upper and lower halves. If Brantley is right, then these conjectured notes would be quite similar in function to those surviving in Bodley 861.

${ }^{101}$ Rouse and Rouse, Manuscripts and Their Makers, 1:147, note the pedantic level of detail in some instructions to illuminators.

${ }^{102}$ In addition to Stowe 39, see the example of Somme le roi in Hannover, Niedersächsische Landesbibliothek, MS I.82, discussed by Rouse and Rouse, Manuscripts and Their Makers, 1:160-61.

${ }^{103}$ Such hypothetical tags could be classified as what Julia Boffey has recently described as "invisible evidence": see Boffey, "Assessing Manuscript Context: Visible and Invisible Evidence in a Copy of the Middle English Brut," in New Directions in Medieval Manuscript Studies and Reading Practices: Essays in Honor of Derek Pearsall, ed. Kathryn Kerby-Fulton, John J. Thompson, and Sarah Baechle (Notre Dame, 2014), 165-76.

Speculum 94/4 (October 2019) 
Again, it is apparent that this note was meant to clarify the ordering of sheets to produce a quire, in this case quire 13, as it now appears in Bodley. The scribe's addressee seems mistakenly to have believed that this overlarge gathering was supposed to begin with Super Orationem, and he was consequently unable to locate the very end of the Exposicio, which appears on the outermost bifolium conjoint with the Marian excerpt from Pseudo-Bonaventure (see Fig. 1). The addressee's mistake is reflected in the signatures visible in Bodley, where the labeling of the quire a $i$, a $i$, and so on began with fol. 143, and fol. 142 was only later labeled $a i$ as well. If the scribe's sheets were loose (and especially if they were unfolded), the mistake would have been easy enough to make, since the bifolium in question contains only twenty lines of the Exposicio in a single column, and a jagged tear runs from the middle of the page at the top to the outer corner at the bottom, making the whole thing look like scrap. ${ }^{104}$ As in the earlier tag, the addressee must have been in possession of the quire being described here when this note was written ("in quaterno vestro"), and it would therefore seem that at least some of the scribe's instructions were written in response to specific questions communicated to him by this correspondent. Further, if accurate, the scribe's claim that all the other quires "have twelve folios" would indicate when, relative to the other booklets, the quire with the Exposicio left the Bodley scribe's hands. Only Booklet II is made up consistently of twelve-folio quires, making Booklet $\mathrm{V}$ the first to be sent after that earlier attempt at serial copying. Of course, the dispatching of booklets need not reflect the order in which the scribe copied his texts, and he could have retained some earlier (but perhaps incomplete) quires after he passed along comparatively finished ones. He may have kept several quires "in progress" at any given time.

The confused state of the sheets described in the earlier note helps to account for the running together of Incendium and Super Canticum in Hereford's Booklet III, but it is harder to see how this second note could have anything to do with the production of that manuscript, where the Exposicio, Super Orationem, and Super Symbolum do not appear. Yet Hereford's omission of these texts, especially the widely copied Exposicio, is significant enough to require some explanation, even apart from the evidence of the Bodley note. Of the twelve manuscripts now containing four or more of Rolle's Latin works, only three, including Hereford, lack the Exposicio. ${ }^{105}$ (And, unlike Hereford, the other two without the Exposicio also omit the Latin Psalter, the other extended example of the Hermit's exegesis.) Likewise, if it is correct to see Hereford as an attempt to present the Bodley scribe's findings in a more polished form, then the absence of Super Threnos, Judica, and Super Psalmum $X X$ is similarly notable, as is the lack of a conscious attempt to include

\footnotetext{
${ }^{104}$ The possibility, raised in both of these notes, that the sheets of Bodley were sent to the Hereford team before being folded may indicate that the rearrangement of Bodley's Booklets III, IV, and V, discussed above, was also carried out before folding. This would perhaps have made the reshufflings less onerous.

${ }^{105}$ In addition to Hereford O.VIII.1, the three manuscripts lacking the Exposicio are Emmanuel 35 and Trinity 153 (on which, see above, n. 23), as well as CUL, MS Dd.5.64. For additional manuscripts with four or more Rolle texts, including the Exposicio, see Cambridge, Corpus Christi College, MS 365, fols. 114r-143r; Lincoln, Cathedral Library, MS 209, fols. 40v-94r; BL, MS Sloane 2275, fols. 140r-150r; New York, Pierpont Morgan Library, MS M.872, fols. 64r-111v; Oxford, Balliol College, MS 224A, fols. 63v-89v; BodL, MS Laud. misc. 528, fols. 42r-77v; Oxford, Corpus Christi College, MS 193, fols. 111v-136r; BnF lat. 15700, fols. 70v-94r.
}

Speculum 94/4 (October 2019) 
Super Canticum, though some of it appears as the conclusion to Incendium. ${ }^{106}$ It is possible, then, that Hereford once contained additional booklets that have subsequently been lost, and that the texts in Bodley's Booklet $\mathrm{V}$, prepared at least in part under the guidance of this note, were included among that material. ${ }^{107}$

If the Hereford scribes produced additional booklets, they must have been parted from the rest early in the manuscript's history, likely before its different fascicles were bound in a single volume, or they may have been bound as a second, companion volume, now lost. The manuscript's earliest known owner is Owen Lloyd (d. 1478), canon of Exeter Cathedral from 1468 and formerly canon of Hereford, as indicated in inscriptions added to some of the twenty-five surviving manuscripts donated to the cathedral library upon his death. ${ }^{108}$ On the flyleaves at the front of Hereford O.VIII.1, Lloyd has supplied a halting list of the manuscript's contents matching its current arrangement:

Contenta sequentis libri

1. Glosa super Psalterium secundum

2. Glosa super Cantica Canticorum secundum

3. Quoddam opus solempne venerabilis heremite Ricardi Hampul continens in se quattuor libros, quorum primus dat Regulam viuendi et continet duodecim capitula, secundus liber De amore Dei, tercius

4. Item glosa super psalmum Quicunque vult et super psalmum Magnificat et super Apocalipsim

Some space is left after the third item on Lloyd's list, which apparently aimed to present the works in Booklets II and III as a single entry. The second item most likely refers not to a commentary on the Song of Songs, but rather to the gloss on the ferial canticles that concludes the Latin Psalter, and Lloyd seems to have been uncertain about the proper attribution of these two glosses (secundum whom?). ${ }^{109}$ Since Lloyd began amassing his collection of books as a student at Oxford in the late 1440s and 1450 s, Hereford must have had at least one owner before it came into his possession, and it remains possible, therefore, that more material was prepared from Bodley than its thirteen bound quires, and that, in this case, the production of Hereford in distinct booklets, with perhaps some deferral before its binding, could have allowed one or more pieces to stray away from the whole. ${ }^{110}$

\footnotetext{
${ }^{106}$ With the omission of Super Threnos-suggesting that, like Booklet V, what we have now of the Hereford scribes' output does not reflect their potential work with Booklet IV-it becomes much harder to know whether the Bodley scribe did finally mean to suggest that the Song commentary on fols. 133r$137 \mathrm{v}$ was Rolle's authentic work as well. Or, to put it the other way, because of the absence of Super Threnos, the absence of the Song commentary in Hereford cannot be taken as a judgment of inauthenticity.

${ }^{107} \mathrm{My}$ collation of Exposicio manuscripts has revealed no extant copy dependent on Bodley 861, and therefore, if the note on fol. 143 was indeed addressed to a scribe preparing a manuscript of that text, the resulting copy has been lost.

${ }^{108}$ A. B. Emden, Biographical Register of the University of Oxford to A.D. 1500, 3 vols. (Oxford, 1957-59), 2:1153-54; Mynors and Thomson, Catalogue of the Manuscripts of Hereford, xxiii-xxiv.

${ }^{109}$ On the ferial canticles and the Latin Psalter, see Kraebel, "The Use of Rolle's Latin Psalter in Richard Ullerston's Expositio Canticorum scripturae,” Medium Evum 81 (2012): 139-44.

${ }^{110}$ Mynors and Thomson, Catalogue of the Manuscripts of Hereford, 53, identify Hereford's binding as fifteenth century. The potential early preservation of late medieval manuscripts in unbound states has been recognized in recent scholarship, even in regard to some especially familiar volumes: see, e.g., Margaret Connolly and A. S. G. Edwards, "Evidence for the History of the Auchinleck Manuscript," The Library, ser. 7, 18 (2017): 292-304.
}

Speculum 94/4 (October 2019) 
Though his list does not point to any potentially missing booklets containing the Exposicio or the other Rolle texts Hereford lacks, Lloyd's ownership of the volume does help to localize both this manuscript and Bodley 861. It is unlikely that Lloyd's manuscript originated in Hereford. Mynors and Thomson note that, beside the standard curricular texts bought from other students during his time at Oxford, Lloyd acquired his books from a number of different institutional libraries throughout his career, including "the Dominicans of Chester, the Cistercians of Neath, and from Leominster Priory," while others "were already at Exeter when Lloyd obtained them." 111 The flyleaves of Bodley 861 include an ex libris from Worcester Cathedral dated 22 March 1590, on the basis of which Ker identified it as part of the priory's medieval library. ${ }^{112}$ A Worcester origin would certainly be consistent with the geographical range described in the marginal note on fol. 10r of Bodley, quoted above. Assuming that the references to Richmond and Hampole are meant to specify places the scribe had scoured "in the north" ("in borientalibus"), the note that he had also looked "in australibus" would seem to describe an area between these northern locales and his more southerly starting point. ${ }^{113}$ All this supports the notion that the scribe began in, and was sending his booklets back to, the West Midlands. If the scribe were a Worcester Benedictine sending his fascicles to his priory, and if his fellow Benedictines were preparing a more formal copy from these booklets, it could have been from Worcester that Lloyd acquired Hereford O.VIII.1, and that volume could have left the priory's library without diminishing the brothers' access to Rolle's Latin texts. ${ }^{114}$

The possibility that the scribes of the Bodley and Hereford manuscripts all belonged to the same monastic community—or, failing that, that they were all active in the area around Worcester-helps to account for the apparently planned production of the two manuscripts. At the same time, their coordination underscores the complexity of the task facing the Bodley scribe, who not only had to locate and copy the Hermit's writings and keep his copies open to revision and reordering, but also

\footnotetext{
${ }^{111}$ Mynors and Thomson, Catalogue of the Manuscripts of Hereford, xxiv. Hanna, "Transmission," 326 n. 34, identifies the medieval provenance of the manuscript as "Hereford Cathedral."

${ }^{112}$ N. R. Ker, Medieval Libraries of Great Britain: A List of Surviving Books, 2nd ed. (London, 1964), 208. In light of the many books adduced by Ker, 205-15, the absence of Bodley from Leland's eleven-item list of Worcester books, assembled c. 1536-40, should not be taken as evidence that the manuscript was not in the priory's library at that date: see Richard Sharpe et al., English Benedictine Libraries: The Shorter Catalogues, Corpus of British Medieval Library Catalogues 4 (London, 1996), 674-75. R. M. Thomson, Descriptive Catalogue of the Medieval Manuscripts in Worcester Cathedral Library (Woodbridge, UK, 2001), xxxiv-xxxv (esp. n. 178), notes that Bodley contains "staplemarks" for chaining that match other known Worcester books.

${ }^{113}$ Allen, Writings Ascribed, 29, suggests that the scribe's "borientalibus" (in the note on fol. 10r, quoted above) is a mistake for either "borealibus" or "orientalibus," casting doubt on the geographical range being described. But DMLBS attests to "borientalis" ("borientali" abl. sg., "borientalibus" abl. pl.) as an adjective meaning "northern" beginning in thirteenth-century English documents, and, especially in light of the contrast with "australis," there seems to be no reason to doubt the scribe's meaning.

${ }^{114}$ Recent work on the medieval libraries of Worcester has focused on Bishop Carpenter later in the fifteenth century: James Willoughby, "Common Libraries in Fifteenth-Century England: An Episcopal Benefaction," in After Arundel: Religious Writing in Fifteenth-Century England, ed. Vincent Gillespie and Kantik Ghosh, Medieval Church Studies 21 (Turnhout, 2011), 212-15; Wendy Scase, "Prelates and the Provision of Books: Bishop John Carpenter's Carnary Library," in The Prelate in England and Europe, 1300-1560, ed. Martin Heale (York, 2014), 127-41. On the priory's library, see Thomson, Manuscripts in Worcester, xvii-xxxviii.
}

Speculum 94/4 (October 2019) 
had to determine when his quires could be sent to his collaborators and how his various decisions regarding the ideal presentation of Rolle's texts could be communicated remotely. It was always possible that he would discover yet another authoritative book-which could account for the selection from Incendium 15 added after Super Symbolum in Booklet V, a passage he may have wished to collate with portions of Booklet II no longer in his possession. ${ }^{115}$ Similarly, in the lower margin of a leaf in the relatively late Booklet I, the Bodley scribe has added two verses he apparently thought should accompany Melos, perhaps like the verses that follow the Exposicio: "Mitto thesaurum dulcius super aurum / In nomine Iesu scriptum sit custoditum" (I send treasure dearer than gold / May what is written in the name of Jesus be your protection). ${ }^{116}$ Here, the scribe may have belatedly found material preserved from an autograph copy of Melos, writing it in the margins of the Latin Psalter because he no longer had access to the relevant quires from Booklet II. Like his decision to copy in single-quire (or, for the Latin Psalter, single-work) booklets and his use of the notes now preserved as tags, these details reflect the limitations imposed on the Bodley scribe's work by his long-distance participation in the making of a second manuscript. In this complexly coordinated scribal enterprise, the plan for that subsequent copy shaped the creation of its exemplar.

\section{Rolle Reimagined}

Whether it reflects the desires of the Bodley scribe or an interest shared by the West Midlands community to which he seems to have belonged, the decision to assemble Bodley 861 and Hereford O.VIII.1 must have begun with an idea of the Hermit of Hampole as an author. It seems hard to imagine, in other words, that this scribe would have journeyed throughout Yorkshire to identify and copy these works if he did not, from the outset, feel that Rolle's devotional sensibilities aligned with his own, that his writings merited anthologizing, and that they were, in some sense, authoritative. At least in part, this interest could be derived without direct reference to Rolle's texts, based perhaps on his reputation as "a figure of exceptional sanctity," or a familiarity with some of the ideas about the religious life advocated in his writings and communicated more easily, apart from those writings, owing to their "intellectual simplicity" and relatively uncomplicated "theological underpinnings." 117 It is

\footnotetext{
${ }^{115}$ Bodley 861, fol. 146va. Incendium, ed. Deanesly, 188-89 n. 6 transcribes the added passage, an abbreviation of the more commonly attested text. The same passage occurs in Durham, Cathedral Library, MS B. IV 35, fol. 112v. In Bodley the passage is followed by a rubric: "Amen qui anno Domini 1049 apud Hampvl monacarum." As Allen, Writings Ascribed, 33, notes, the date clearly contains an error, but it is difficult to be certain whether it should read " 1349 ," the date of Rolle's death, or "1409," potentially the year in which the scribe copied the passage, in which case it may indicate that the scribe was copying it from a Hampole manuscript.

${ }^{116}$ Bodley 861, fol. 7v. The verses are headed "Ricardus Hampul Heremita de vita perfecta," reminiscent of Rolle's reference, in the Exposicio, to his "Liber de perfeccione et gloria sanctorum" (Moyes, 2:196), which Watson, Invention of Authority, 172, persuasively identifies with Melos. Then again, the title could also plausibly refer to Emendatio vitae. See Allen, Writings Ascribed, 24; Hanna, Editing Medieval Texts, 142.

${ }^{117}$ See, respectively, Hanna, "Transmission," 329; and Nicholas Watson, “The Middle English Mystics," in The Cambridge Historv of Medieval English Literature, ed. David Wallace (Cambridge, UK, 1999), 539-65, at 549 .
}

Speculum 94/4 (October 2019) 
also possible, based on his judgment about the age of different books, that the scribe had access to some of Rolle's texts in copies he knew to be belated and potentially unreliable: his journey certainly seems to have been prompted by a desire not just to copy Rolle's works, but to copy them from good manuscripts, perhaps specifically autographs. He may very likely have possessed what he thought was an authoritative copy of Emendatio before his journey began, the copy used as an exemplar by the Hereford team, and (though other scenarios are of course possible) recalling that this text was at home may have led him quickly to abandon copying it on the bifolium that now bears the end of Super Apocalypsim. In Emendatio, Rolle's mature and confident "articulation of his personal experience of the spiritual life as one of its definitive forms," the scribe would have found exemplified, among other things, a devotion to the Holy Name that may explain his own habit of copying the monogram "Jhü" at the top of every page (see, e.g., Fig. 3). ${ }^{118}$

Whatever the Hermit's initial appeal, the scribe's understanding of Rollean authority appears to have developed significantly over the course of his undertaking, at the same time as he came to appreciate the need to consider whole books as potentially bearing traces of Rolle's writing, and as he wrestled with ways of conveying his discoveries to the team of scribes back home. The Bodley scribe's shifting notions of his author are most clearly revealed not in his written annotations, however, but in the marginal illustrations that he supplied throughout his booklets. Some of these images are mnemonic representations reflecting the contents of the nearby text, such as the lion appearing alongside the Exposicio's description of a sinner "qui crudelis vt leo vixerat" (Fig. 7a). ${ }^{119}$ More frequently, the scribe depicted bodiless angels who use their feathery wings to draw attention to a particular line of text, working as elaborate manicules (Fig. 7b-d). ${ }^{120}$ Perhaps indicative of the scribe's monastic affiliations, in almost all cases these angelic heads are tonsured. That they are the work of the Bodley scribe is confirmed by the consistency of the ink used in the text and images: some are clearly copied in the text ink $(7 \mathrm{c})$, while others have been added as the scribe rubricated specific quires $(7 \mathrm{~d})$. In a few cases, the scribe first drew in text ink and then used red ink either to add further details (7b) or to draw over the earlier image entirely (7a). Based on the order of production established above, the images began in the scribe's copy of Melos, and it is tempting to associate them with the "angelica harmonia" and "canor" described throughout that text. ${ }^{121}$ The scribe, that is, may have used the margins of his booklets to imagine the ecstatic experiences advocated in Rolle's writings.

\footnotetext{
${ }^{118}$ Richard Rolle, Emendatio vitae, Orationes ad honorem nominis Ihesu, ed. Nicholas Watson, Toronto Medieval Latin Texts 21 (Toronto, 1995), 22. A prayer to Jesus begins Emendatio 11, ed. Spahl, 212-14. On Rolle and the cult of the Holy Name, see Denis Renevey, "Name above Names: The Devotion to the Name of Jesus from Richard Rolle to Walter Hilton's Scale of Perfection I," in The Medieval Mystical Tradition: England, Ireland, Wales; Exeter Symposium VI, ed. Marion Glasscoe (Cambridge, UK, 1999), 103-21; Jennifer Depold, "Preaching the Name: The Influence of a Sermon on the Holy Name of Christ," Lournal of Medieval History 40 (2014): 195-208, with reference to further studies at 195 n. 1.

${ }^{119}$ Bodley 861, fol. 157v; Moyes, Introduction and Contribution, 2:212, line 6.

${ }^{120}$ Allen, Writings Ascribed, 23, notes the preponderance of angels among the marginal drawings in Bodley. These angelic figures appear in every booklet except IV and VI.

${ }^{121}$ E.g., Melos, ed. Arnould, 12, line 31; 45, line 16; 54, line 4. On Rolle's ideas of angelic song, see now Andrew Albin, "Listening for Canor in Richard Rolle's Melos amoris," in Voice and Voicelessness in Medieval Europe, ed. Irit Ruth Kleiman (New York, 2015), 177-97.
}

Speculum 94/4 (October 2019) 


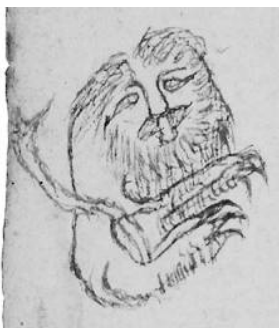

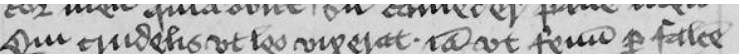

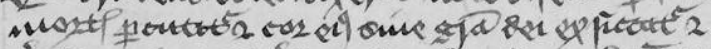

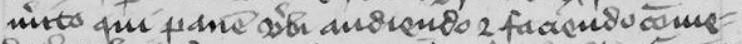

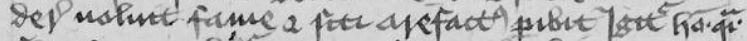

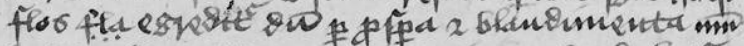

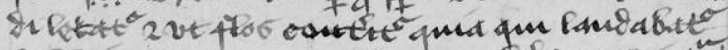

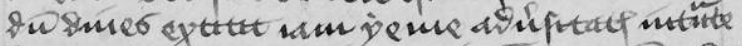

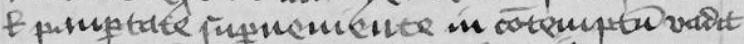

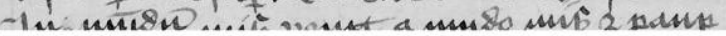

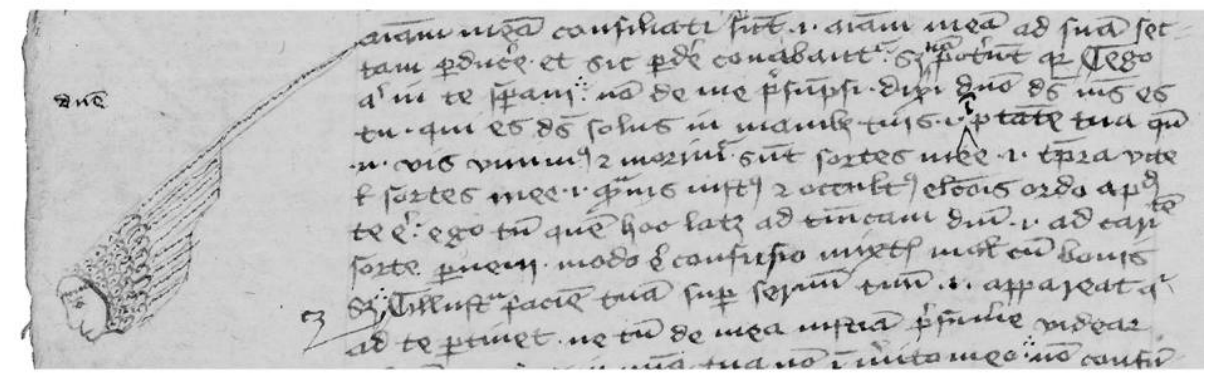

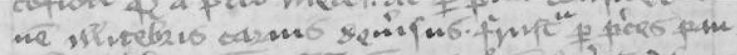

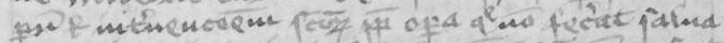

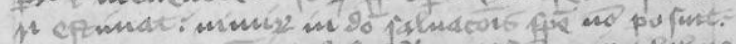

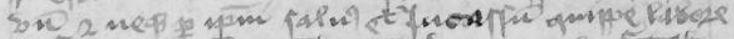

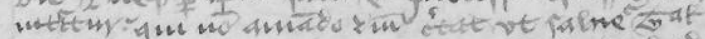

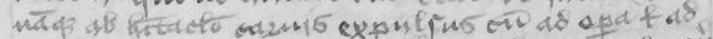

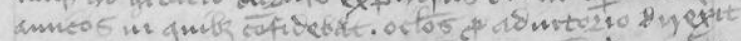

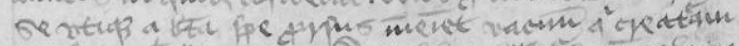

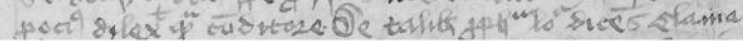

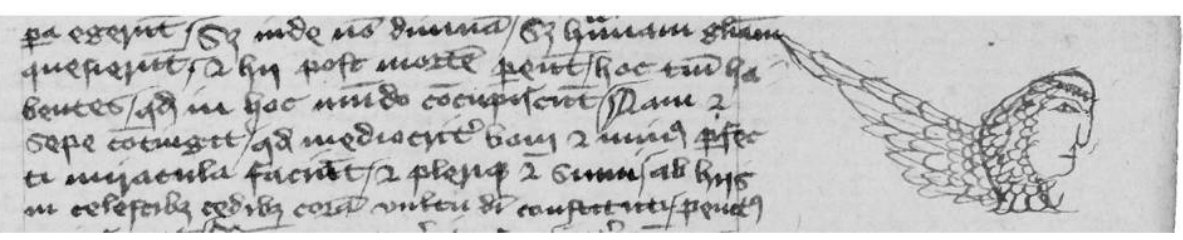

Fig. 7. Scribal drawings in Bodley 861. (a) fol. 157v: cruel lion in rubric and text ink in Expositio 5; (b) fol. 12v: angel drawn in text ink and decorated with red ink, pointing to the Latin Psalter on Ps. 30.14, with marginal and interlinear corrections; (c) fol. 88r: angel in text ink pointing to a line in Super Canticum 6; (d) fol. 104r: angel in red ink pointing to a line in Incendium 3. See the online edition for a color version of these images.

He also used this space to depict the author himself. ${ }^{122}$ Among the various heads copied in Bodley 861, several stand apart as apparent attempts to reproduce, across the manuscript, a single and distinctive figure. Unlike the heads in Fig. 7, these include neither wings nor tonsures-indeed, this figure has long hair pulled back from

\footnotetext{
${ }^{122}$ Recent scholarship on late medieval author portraits has tended to focus on professional productions, images whose supply was anticipated, whether as decorated initials or in fuller scenes in the central space of the page. See Christel Meier, "Ecce auctor: Beiträge zur Ikonographie literarischer Urheberschaft im Mittelalter," Frübmittelalterliche Studien 34 (2000): 338-92; Kathleen Scott, "Representations of Scribal Activity in English Manuscripts, c. 1400-c. 1490: A Mirror of the Craft?," in Pen in Hand: Medieval Scribal
}

Speculum 94/4 (October 2019) 

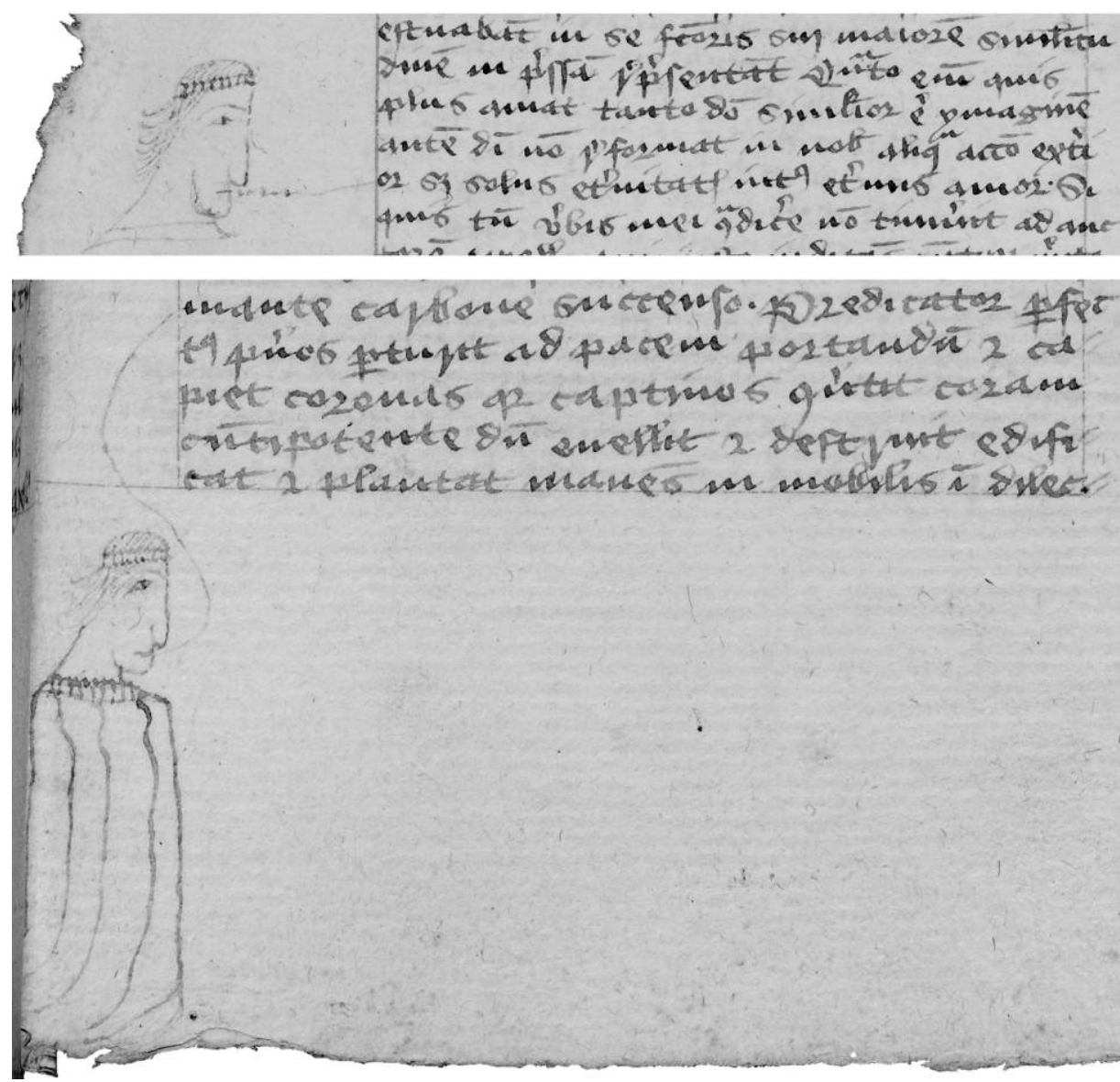

Fig. 8. Author portraits in Bodley 861. (a) fol. 73v: speaking a passage from Melos 47; (b) fol. 74r: speaking a passage from Melos 48. See the online edition for a color version of these images.

his face by a thin fillet. As with his marginal angels, the scribe first attempted to depict this figure while copying Melos, and two similar heads (the second including a body in a long robe) appear across the opening of fols. $73 \mathrm{v}-74 \mathrm{r}$ (Fig. $8 \mathrm{a}-\mathrm{b}$ ). In both cases, a line emerges from the figure's mouth to join it to a specific point in Rolle's prose. The first head $(8 \mathrm{a})$ is thus tied to a line of text containing the end of one sentence and the beginning of another:

Portraits, Colophons, and Tools, ed. Michael Gullick (Walkern, UK, 2006), 115-49; Ursula Peters, Das Ich im Bild: Die Figur des Autors in volkssprachigen Bilderhandschriften des 13. bis 16. Jahrhunderts, Pictura et Poesis 22 (Cologne, 2008); Sonja Drimmer, "Visualizing Intertextuality: Conflating Forms of Creativity in Late Medieval 'Author Portraits,"' in Citation, Intertextuality, and Memory in the Middle Ages and Renaissance, vol. 2, Cross-Disciplinary Perspectives on Medieval Culture, ed. Giuliano Di Bacco and Yolanda Plumley (Liverpool, 2013), 82-101. For studies of scribal artists, see Brantley, Reading in the Wilderness, and Kathryn Kerby-Fulton and Denise Despres, Iconography and the Professional Reader: The Politics of Book Production in the Douce "Piers Plowman" (Minneapolis, 1998).

Speculum 94/4 (October 2019) 
Ymaginem autem Dei non reformat in nobis aliqua accio exterior, sed solus eternitatis intus eternus amor. Si quis tamen verbis mei[s] contradicere non timuerit, ad Auctorem appello qui iuste iudicans cuntorum merita disponit. ${ }^{123}$

[No exterior action reforms God's image in us, but only the unending love of eternity within. If anyone dare to contradict my words, I appeal to the Author who orders and justly judges the merits of all cases.]

Though the first sentence, copied at the level of the figure's eyes, is stereotypically Rollean, it seems more likely that the second, beginning at the very end of the line of text to which the figure's mouth is tied, is what prompted the scribe to draw this head. Its defiant appeal to God as judge, and especially the reflexive reference to the text as Rolle's words ("verbis meis"), are met in the margin with a figure that speaks those words, a portrait of the author. This identification is supported by the figure on the facing page (8b), tied to another strong statement of the Hermit's authority:

Predicator perfectus pueros parturit ad pacem portandum, et capiet coronas quia captiuos conuertit coram Cuntipotente, dum euellit et destruit, edificat et plantat, manens inmobilis in dileccione diuina. Profecto percipiet diadema decoris et reuerenter in regno cum rectis recidebit. ${ }^{124}$

[The perfected preacher bears children to bring forth peace, and he will receive crowns in the presence of the Almighty because he converts captives, when he uproots and destroys, builds and plants (cf. Jer. 1.10), remaining immobile in divine love. Undoubtedly, he will win a decorous diadem (cf. Ws. 5.17) and will reside reverently in the kingdom with the upright.]

From the perspective of the Bodley scribe, the dead author has indeed now secured the heavenly crowns anticipated in this passage, and it could be this sense of Rolle's triumph that prompted him to depict the Hermit speaking these sentences. Yet something more specific may have drawn him to these lines in particular, especially since (as Watson observes) they form part of a much longer discussion in which Rolle describes his "place within the structure of the Church Militant" as "a practitioner of the only form of 'mixed' life which can truly combine the height of contemplative ecstasy with the service of others." ${ }^{125}$ It could be significant, then, that Rolle does not just discuss himself in these lines, but also invokes the "pueri" to whom he has given birth through his (written) preaching. The scribe may have understood himself to be among these children of Rolle, and he may have been particularly eager to draw attention to this passage for its inclusion of devoted readers like himself in the Hermit's conception of his authorial program.

Significantly, then, neither of these portraits focuses attention on a passage featuring the characteristic components of Rolle's religious experiences, the heat, sweetness, and song about which he so frequently writes. In this regard, these previously unnoted portraits differ from those accompanying the Middle English Desert of Religion in BL, MS Cotton Faustina B. vi (part 2), fol. 8v, and BL, MS Add. 37049,

\footnotetext{
${ }^{123}$ Bodley 861, fol. 73va; cf. Melos, ed. Arnould, 149, lines 3-7.

${ }^{124}$ Bodley 861, fol. 74ra-b; cf. Melos, ed. Arnould, 152, lines 12-16.

${ }^{125}$ Watson, Invention of Authority, 185.
}

Speculum 94/4 (October 2019) 
fol. $52 \mathrm{v}$, or the related image in Add. 37049 , fol. 37r, where (in all three cases) the ecstatic solitary sits in the wilderness beneath a choir of singing angels. ${ }^{126}$ They are different, too, from the depiction of Rolle appearing in a vision to a suppliant on a leaf added at the opening of Laud. misc. 528. ${ }^{127}$ To be sure, in these other examples an open book held in his arms or on his lap identifies Rolle as an author, but this detail is secondary compared to any number of other features: his status as a hermit, his experience of angelic song, or his postmortem apparitions. ${ }^{128}$ The scribal illuminator of Bodley 861, in contrast, simply emphasizes the fact of Rolle's authority as a writer, someone whose words deserve the sort of careful attention he was devoting to them. ${ }^{129}$

Additional portraits at other points in his booklets indicate not just the Bodley scribe's continued devotion to Rolle as author, but also his developing interest in the sources of that authority-in the specific ways, that is, that Rolle came to be an authoritative writer. One of the next points in the text to capture his interest occurs in the Exposicio, added in the course of rubricating (and, at least in part, reading) the text (Fig. 9a). ${ }^{130}$ The fillet is reduced to a single jagged line, but the tall face and (especially) long hair identify this figure with the one depicted in Melos. Again, a line ties the figure's lips to a specific point in the Hermit's writings, including some of the lemmata parsed in the commentary (Job 10.2): "Ergo indica michi cur me ita iudices. Inspira mentem et indica causam. Ita stricte iustum iudicas vt peccatores terreas ..." (Therefore show me why you judge me this way. Inspire my mind and show me the cause. You judge the just one strictly in this way to frighten sinners . . .). ${ }^{131} \mathrm{By}$ choosing to respond to this startling prayer for inspiration ("inspira mentem"), the scribe suggests not just his belief in the Hermit's authority but, more specifically, his interest in Rolle as an exegete whose interpretations derive from some kind of

\footnotetext{
${ }^{126}$ On these images, see Brantley, Reading in the Wilderness, 138-47, with reproductions.

${ }^{127}$ For a reproduction, see William F. Pollard, "Richard Rolle and the "Eye of the Heart," in Mysticism and Spirituality in Medieval England, ed. William F. Pollard and Robert Boenig (Cambridge, UK, 1997), 85-106, at 89. Steven Rozenski, "Authority and Exemplarity in Henry Suso and Richard Rolle," in The Medieval Mystical Tradition in England: Papers Read at Charney Manor, July 2011; Exeter Symposium VIII, ed. E. A. Jones (Cambridge, UK, 2013), 93-108, at 96-97, draws attention to a smaller haloed head added after the attribution of Incendium to Rolle in Laud. misc. 528, fol. 97v; a similar haloed head appears in a decorated initial at the start of Incendium on fol. 78r. Rozenski argues that these portraits emphasize "the identification of author-character with text" and "the association of autobiography with author." In contrast, the heads in Bodley 861 allow for a more specific association of particular moments in the text with the authorial persona.

${ }^{128}$ See the visionary appearances recorded in the Officium and Miracula, ed. Woolley, 82, 84-85.

${ }^{129}$ In this regard, these author portraits are similar to the pictures of patristic authorities added in Herbert of Bosham's copy of the Magna glosatura, now Cambridge, Trinity College, MS B.5.4 and BodL, MS Auct. E inf. 6. The figures in Herbert's manuscripts, however, draw attention to places where the Lombard had misattributed glosses to specific authors-the fathers intervene to distance themselves from the interpretive claims. See Mary Carruthers, Book of Memorv: A Studv of Memorv in Medieval Culture, $2^{\text {nd }}$ ed., Cambridge Studies in Medieval Literature 70 (Cambridge, UK, 2008), 267-68; Stella Panayotova, "Tutorial Images for Thomas Becket," in The Cambridge Illuminations: The Conference Papers, ed. Panayotova, Studies in Medieval and Early Renaissance Art History 52 (Turnhout, 2007), 77-86.

${ }^{130}$ Apart from the lion in Fig. 7a, rubrication in the Exposicio stops after fol. 154v.

${ }^{131}$ Bodley 861, fol. 152rb; cf. Moyes, Introduction and Contribution, 2:163, lines 15-17.
}

Speculum 94/4 (October 2019) 

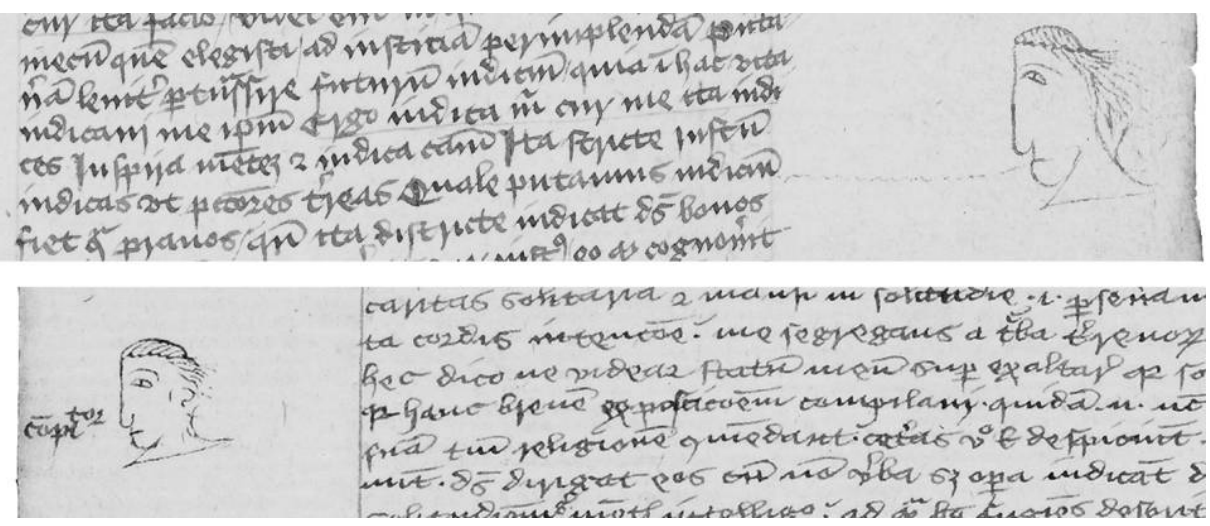

Fig. 9. Author portraits in Bodley 861. (a) fol. 152r: in red ink flanking a passage in Exposicio 2; (b) fol. 19v: the compiler in text ink beside the Latin Psalter on Ps. 54.8. See the online edition for a color version of these images.

divine revelation. ${ }^{132}$ Yet that is by no means an inevitable interpretation of the voicing of this passage: since Rolle begins by quoting the biblical text, it is unclear whether the imperative "inspira" (parallel to Job's "indica") is spoken by the exegete, the biblical author, or the anonymous "vir iustus" in whose voice Rolle soon thereafter claims that Job was writing. ${ }^{133}$ This understanding of the Hermit's inspiration may be closer to the enraptured mystic depicted in Cotton Faustina B. vi and Add. 37049, but its focus on the comparatively derivative or secondary category of exegetical prose also aligns with the textual-authoritative preoccupations of the earlier Bodley portraits. ${ }^{134}$

The scribe's last depiction of Rolle, added while he copied or corrected the Latin Psalter, carries this sense of the author's potential unoriginality even further (Fig. 9b). This final figure differs slightly from the earlier three, with the head less elongated and a slight curve introduced to the outline of the nose, changes consistent with the scribe's drawings throughout Booklet I (cf. Fig. 7b). Though it is not tied to a line in the Psalter, the relevance of the nearby passage (fol. 19va) is clear:

Ecce elongaui fugiens (non tam loco quam mente: non est enim caritas solitaria) et mansi in solitudine, id est perseueraui in remota cordis intencione, me segregans a turba terrenorum desideriorum. Hec dico ne videar statum meum superexaltare, quia solitarius sum q[ui] hanc breuem exposicionem compilaui.

[Lo, I have gone far off fleeing (not so much in place as in mind, for love is not solitary) and I dwelt in solitude, that is, I persevered in the hidden intention of my heart, separating myself from the crowd of earthly desires. I say this so I do not appear too much to praise my own state, since I who compiled this brief exposition am a solitary.]

${ }^{132}$ For discussions of Rolle as an inspired exegete, see Watson, Invention of Authority, 5, 97-103; Bernard McGinn, The Varieties of Vernacular Mysticism, 1350-1550, The Presence of God 5 (New York, 2012), 342.

${ }^{133}$ Moyes, Introduction and Contribution, 2:163, line 18. For discussion of Rolle's creative voicing of commentaries, see Kraebel, Experiments in Interpretation, Chapter 3.

${ }^{134}$ In contrast, Brantley, Reading in the Wilderness, 142-47, describes the focus of the Desert of Religion on Rolle as a charismatic speaker (or singer) of lyric poetry; Rozenski, "Authority and Exemplarity," reads the portraits in Laud. misc. 528 as reflecting the heavily autobiographic quality of Incendium.

Speculum 94/4 (October 2019) 
Again, the Bodley scribe has drawn attention to a passage focused on Rolle as a writer of commentaries, but here the Hermit presents himself not as an inspired exegete but a humble compiler, in line with his claim to have read Ps. 54.8 spiritually to avoid the appearance of conceitedly praising his eremitical profession. ${ }^{135}$ The scribe appears to have been less interested in this account of Rolle as hermit and more in the verb he uses to describe his writing, "compilaui," echoed in the label "compilator" he added alongside his portrait. Though the title seems more quotidian, Rolle as compiler need not be less authoritative or inspired. Indeed, the scribe appears to have found this passage remarkable because, much like what he apparently took as a claim of inspiration in the Exposicio, the identification of Rolle as a compiler helps to account for the source of his authority-that the scribe was, in other words, developing an understanding of Rolle's authority as deriving at once from ecstatic inspiration and from the careful compilation of other authoritative writings. ${ }^{136}$

Of course, the scribe's understanding of the author whose works he assembled should not be limited to these four attempts at portraiture made over the course of at least two years. ${ }^{137}$ At the very least, however, the consistency of his depictions and their appearance in three different booklets indicate that the contours of Rolle's authorial persona and the status of his authority were recurrent concerns throughout the scribe's work of assembling and copying. Further, keeping in mind what appear to be the scribe's uncertainty and open-mindedness regarding the contents of the Hermit's corpus, his positioning of these portraits at such different moments in Rolle's writings suggests that his understanding of this authorial persona was changing in response to the texts and books he found. The authoritative writer of Booklet II thus becomes, in Booklet $\mathrm{V}$, an inspired author of biblical exegesis. Indeed, in light of what appears to be his realization of the need to consider whole books as authoritative bearers of Rolle's works, it may be unsurprising that the Hermit's self-identification as a "compilator" caught his attention and prompted his last portrait. The possibility that Rolle not only copied and compiled his own works, but also, in the course of assembling these books or booklets, may have revised preexisting filler or created short texts of his own to fill space, fits neatly with the description of his activities in creating the Latin Psalter from preexisting glosses. ${ }^{138}$ Here, in other words, the Bodley scribe may have found an idea of the author that could account for the complex diffusion of inconsistent copies and unclearly attributed works that created such difficulties for his

\footnotetext{
${ }^{135}$ He shows no such concern when glossing the same verse in Melos, ed. Arnould, 144.

${ }^{136}$ The Bodley scribe's consistent focus on Rolle's authority as a writer (in a way distinct from his sanctity or mysticism) could help to account for his failure to include the Officium and Miracula compiled at Hampole in anticipation of his canonization. His notes (e.g., on fol. 10r) indicate that he did look for exemplars in Hampole, and it seems hard to imagine that he would not have had access to this text if he wanted to include it in his compilation. Unlike Bodley, the Corpus/Cotton collection includes Officium and Miracula, in Cotton Tiberius A. xv, fols. 191v-194v. See Andrew Albin, "Canorous Soundstuff: Hearing the Officium of Richard Rolle at Hampole," Speculum 91/4 (2016): 1026-39.

${ }^{137}$ To this group, one further portrait may be added, on fol. $152 \mathrm{v}$, alongside the text of the Exposicio, Moyes, 2:165, line 20-166, line 2. Though there are further first-person pronouns in this text (again, developing Job 10.2), it seems harder to explain the scribe's decision to depict Rolle here in terms of this material. It may be that this comparatively poorly executed portrait was meant to draw further attention to the nota mark the scribe also added (in red) at this point.

${ }^{138}$ Of course, Rolle also included many interpretations of his own devising in both his Latin and English Psalters—see Kraebel, Experiments in Interpretation, Chapter 3.
}

Speculum 94/4 (October 2019) 
task of reassembling the Hermit's writings. In contrast to more common accounts of Rolle as an eccentric figure preoccupied by the need "to establish and exercise" his particular "form of eremitic and mystical authority," and whose appeal to late medieval readers was correspondingly dominated by the "portrayal of his own experiences" in his writings, the Bodley scribe seems to have been especially drawn to the idea of Rolle as the scribal author of the books he discovered on his journey. ${ }^{139}$ And it is tempting to see something of the Bodley scribe himself reflected in this final depiction of an authoritative compiler: toward the end of his protracted enterprise, the scribe may have been gratified to find the Hermit describing himself in terms that could fittingly apply to this scribe's own labor as well. ${ }^{140}$

As a group, these scribal portraits indicate that, even as he devoted himself to collecting, copying, and comparing many books bearing Rolle's writings, the Bodley scribe was not only interested in pedantic or practical issues-he was, at the same time, also developing ideas about the Hermit as a writer, what might be called theories of Rolle's authorship. These portraits are, in other words, visual and material correlatives of the priorities discernible in the complex processes of his book's assembly. The scribe's engagement with these ideas is now only recoverable with any degree of confidence by virtue of the textual and pictorial annotations that he made throughout his volume-and the near necessity of this evidence is made clear when Bodley is put beside Hereford. If, as suggested above, the scribe of Bodley was a member of the same religious community that also produced Hereford, it would then seem likely that at least some of the scribes working on that second manuscript shared at least some of the ideas about Rolle (as a writer, as a religious authority) that informed the Bodley scribe's work. Yet, because his notes indicate that this scribe made an effort, remotely, to oversee Hereford's copying, and despite the marginal annotations present in that second manuscript, there is simply no way of knowing what the Hereford scribes thought about the author whose texts they copied or how those judgments might have informed their work. They may have been eager to read the Hermit's writings, or, if they were simply following the Bodley scribe's instructions, they may not have known anything about those writings or their author.

This contrast in what can now be known about the role of supratextual concerns in the making of these two anthologies-understandings of the author and judgments about the status of exemplars-indicates the importance of attending to the details of manuscripts that are, like Bodley, unusually messy. To be sure, Daniel Wakelin is right to advocate that more critical attention be devoted to comparatively "boring" books, ones which, like Hereford, lack the awkward reshufflings and reflexive annotations characterizing the Bodley scribe's efforts. ${ }^{141}$ These cases, in which scribes

\footnotetext{
${ }^{139}$ Watson, Invention of Authority, xi; Rozenski, “Authority and Exemplarity,” 101.

${ }^{140}$ Cf. Michael Camille's claim that marginal figures, "as extensions of their own bodies into the text, mark a point of entry for the reader into the book," and that they are often "representations of internal readers" and "cues for the reader's own eyes": Camille, "Glossing the Flesh: Scopophilia and the Margins of the Medieval Book," in The Margins of the Text, ed. D. C. Greetham (Ann Arbor, 1997), 245-68, at 257. See too Seth Lerer's reading of John Shirley as copyist of the "Adam Scriveyn" lyric attributed to Chaucer: Lerer, Chaucer and His Readers, 117-46; extended and critiqued by Alexandra Gillespie, “Reading Chaucer's Words to Adam," Chaucer Review 42 (2008): 269-83.

${ }^{141}$ Daniel Wakelin, "In Plain Text: Reading Boring Manuscripts,” paper presented at the Biennial Meeting of the New Chaucer Society, London, July 2016. Professor Wakelin is revising this talk for inclusion in a monograph-my thanks to him for sharing the typescript of his conference paper.
}

Speculum 94/4 (October 2019) 
produced tidier volumes and felt less need to comment on their work, account for the bulk of manuscripts surviving from the later Middle Ages, and it is crucial that we develop more rigorous methods for approaching their seeming normalcy. My suggestion here is that much of that work will depend on what we can learn from messier manuscripts. Especially outside commercial production, in circumstances where, as Jean-Pascal Pouzet observes, decisions to copy were driven primarily by "local circumstances and motivations," it seems likely that scribes would have to exercise some judgment about what they copied. ${ }^{142}$ Yet direct evidence of those judgments will almost certainly only be preserved in exceptional cases like the Bodley anthology. It is only because of his unusually detailed annotations, instructions, corrections, and illuminations that the Bodley scribe's understanding of Rolle as a scribal author can now be discerned, but he cannot have been the only later medieval scribe to consider the possibility that the works he copied were first written (in all senses) by an author, and to carry out his work in light of that understanding. This potential for scribal judgment-judgment based on commitments to and notions of textual authority and authorship—-may have helped to shape even the most boring medieval manuscripts.

${ }^{142}$ Jean-Pascal Pouzet, "Book Production outside Commercial Contexts," in Production of Books in England, ed. Gillespie and Wakelin, 212-38, at 216.

Andrew Kraebel is Assistant Professor of English, Trinity University, San Antonio, TX (e-mail:akraebel@trinity.edu) 